الأنشطة اليدوية كمدخل لتهيئة طفل الروضة للتفكير

بعقلية ريادي هستقبلي صغير 1

\author{
إعداد \\ دا دايمان عبد الحي همهد شلبي
}

الأستاذ المساعد بقسم رياض الأطفال، كلية التربية، جامعة جازان

أ/ سعيدة هسعود سلهان جبران أ / أثير يحيى علي جبريل كلية التربية - جاهعة جازان لية التربية التربية - جاهعة جازان

1 * هذا البحث يتبع الملتقى العلمي العاشر لطلاب وطالبات جامعة جازان، باحث المستقبل 7، كود (020-10Fs

* تثكر الباحثات عمادة البحث العلمي بجامعة جازان.

د. ريمان عبد الحى محمد شلبي (باحث رئيسي ).

أ ـ سعيدة مسعود سلمان جبران (باحث مشارك).

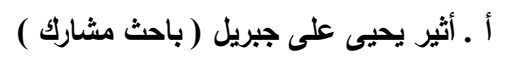


الأنشطة اليدوية كمدخل لتهيئة طفل الروضة للتفكير بعقلية ريادي مستقبلي صغير

ريمان عبد الحي محمد شلبي، سعيدة مسعود سلمان جبران، أثير يحيى علي جبريل قسم رياض الأطفال، كلية التربية، جامعة جازان، المملكة العربية السعودية. البريد الاكتروني: rshibil@jazanu. edu. sa

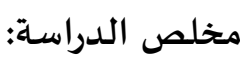

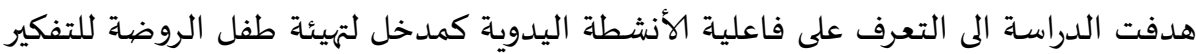

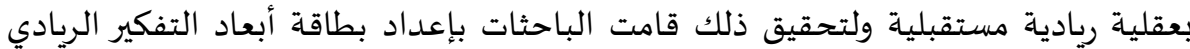

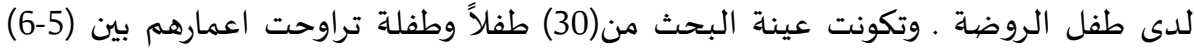

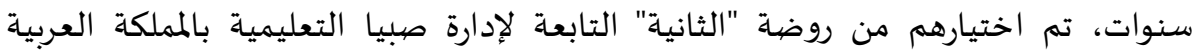

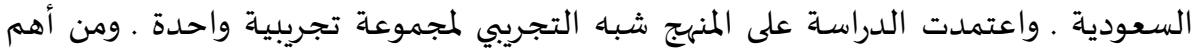

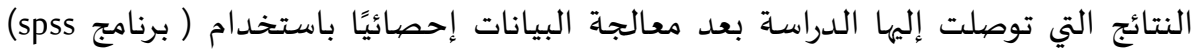
وحساب المتوسط الحسابي واختبار" ت" وتوصلت الدراسة إلى الي:

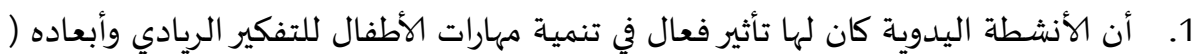

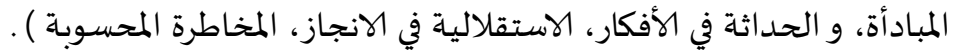

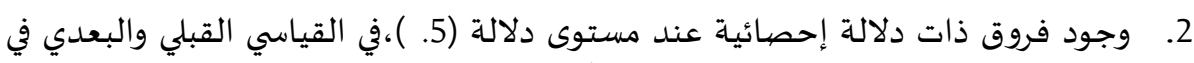

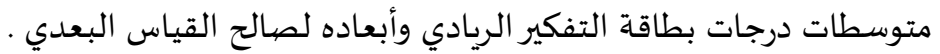

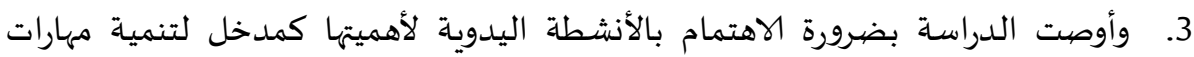

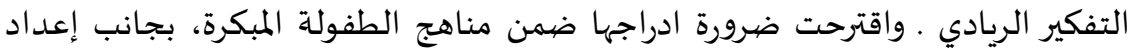

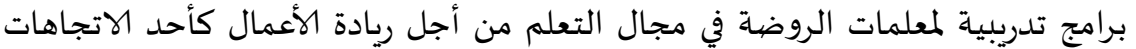

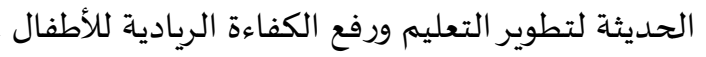
الكلمات المفتاحية: الأنشطة اليدوية، التفكير الريادي، ريادة الأعمال، طفل الروضية . 

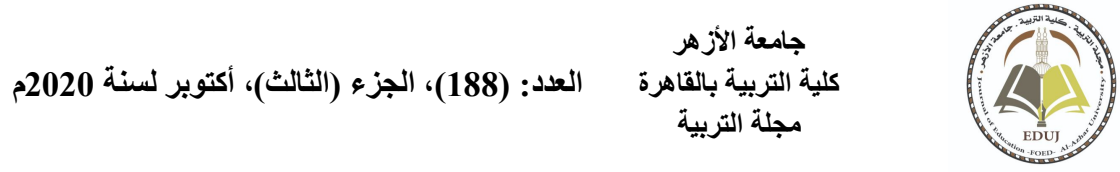

Manual activities as an input to prepare kindergarten to think as a small future entrepreneurial mindset

\author{
Reman Abdel-Hay Mohamed Shalaby*, Saeed Masoud Salman \\ Jubran, Aseer Yahya Ali Gabriel \\ Department of Kindergarten, faculty of Education, Jazan \\ University, KSA.
}

*Email: rshibil@jazanu.edu.sa

\begin{abstract}
:
The study aimed to identify the effectiveness of manual activities as an entry point to prepare the kindergarten child to think with a future entrepreneurial mentality. To achieve this, the researchers Use the observation method of the dimensions of entrepreneurial thinking in the kindergarten child. The sample of the research consisted of (30) children, their ages ranged between (5-6) years, who were chosen from the "second" kindergarten of the Sabya Educational Administration in the Kingdom of Saudi Arabia. The research relied on the quasiexperimental approach of one experimental group. Among the most important results of the research after processing the data statistically using (spss program) and calculating the arithmetic mean and the "T" test. The study concluded. 1. The manual activities had an effective effect in developing children's skills for entrepreneurial thinking and its dimensions (initiative, novelty in ideas, independence in achievement, and calculated risk). 2. The existence of statistically significant differences at the level of significance (5.), in the pre and post measurements, in the mean scores of the entrepreneurial thinking card and its dimensions in favor of the post measurement. 3. The study recommended the necessity of paying attention to manual activities due to their importance as an entry point for developing entrepreneurial thinking skills. And it was suggested that it should be included in early childhood curricula, in addition to preparing training programs for kindergarten teachers in the field of learning for entrepreneurship, as one of the modern directions for developing education and raising the competence of entrepreneurship.
\end{abstract}

Keywords: manual activities, entrepreneurial thinking, entrepreneurship, kindergarten child 


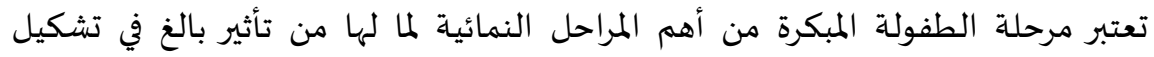

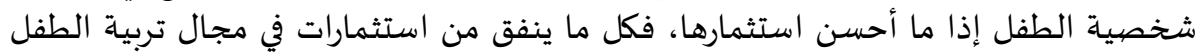

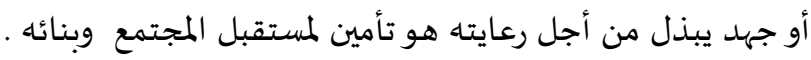

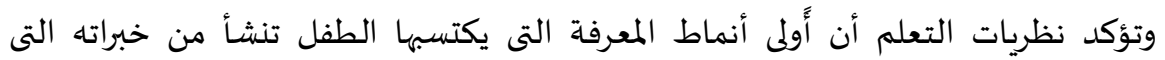

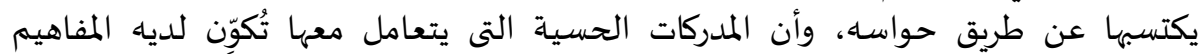

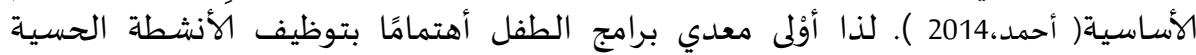

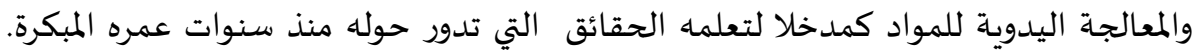

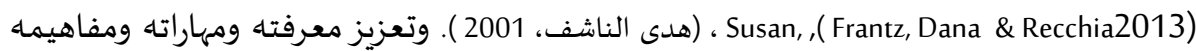

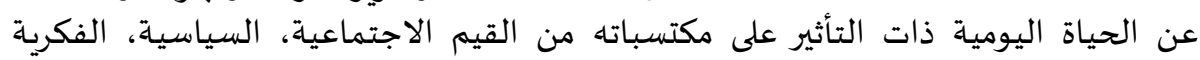

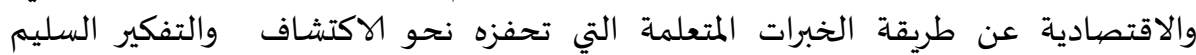
والمشاركة في المجتمع كمشارك فعال (KOla, 2005).

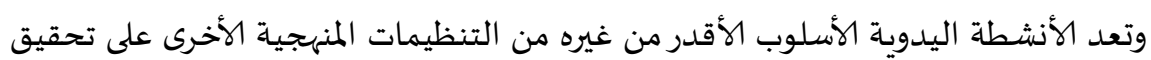

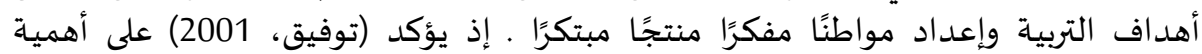

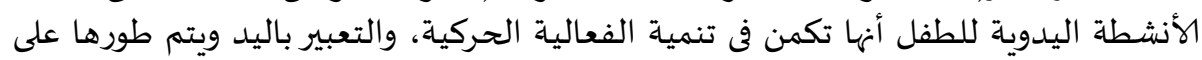

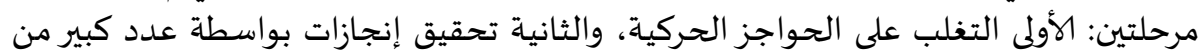

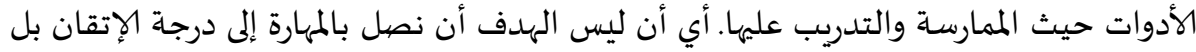

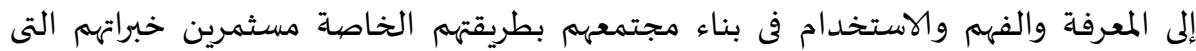

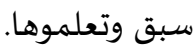

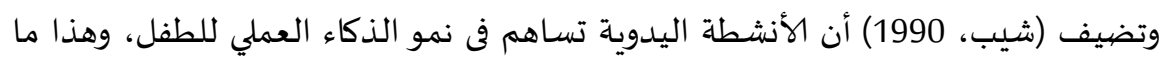

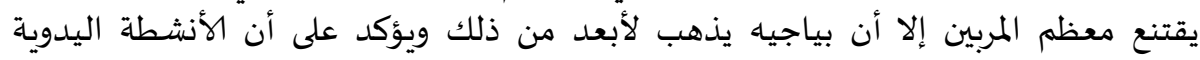

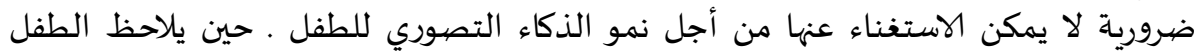

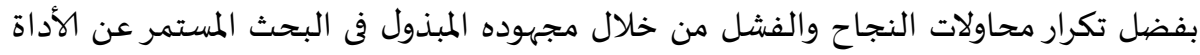

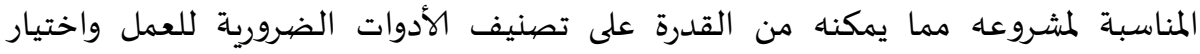

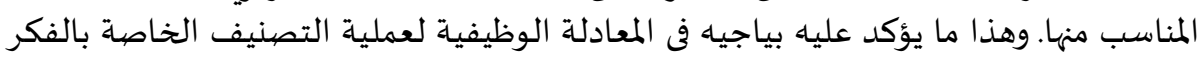

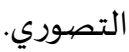

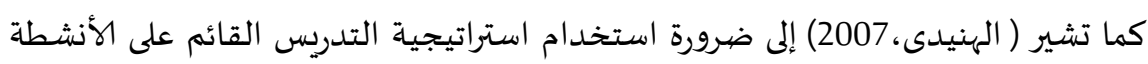

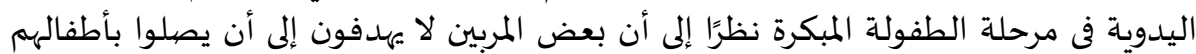

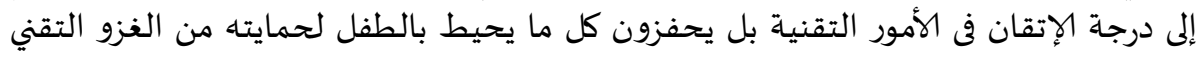

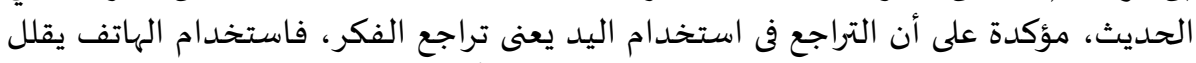

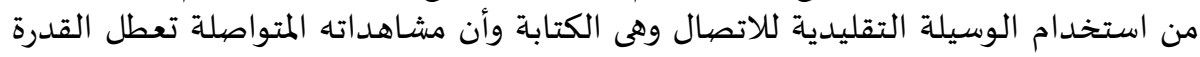

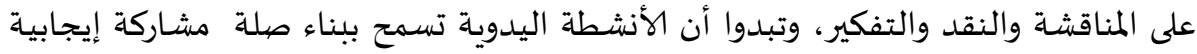

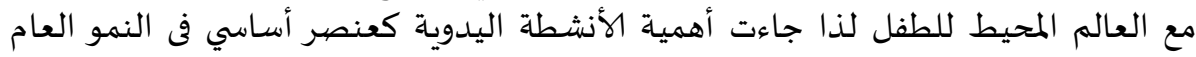

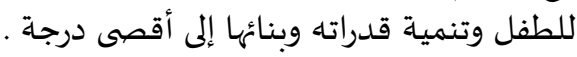




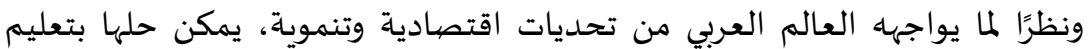

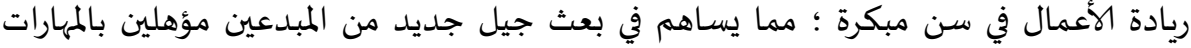

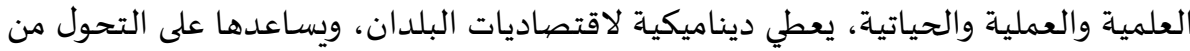

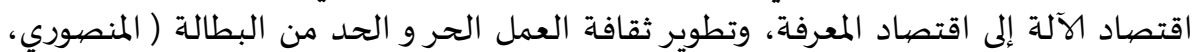

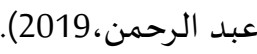

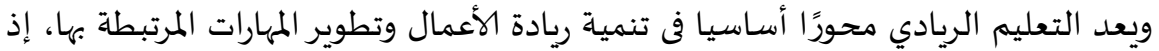

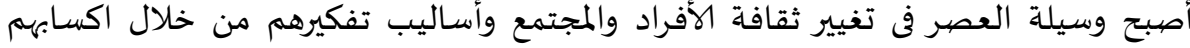

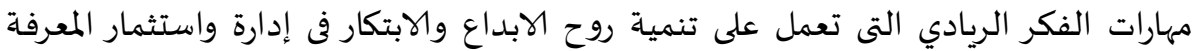

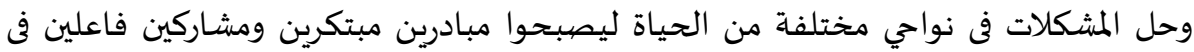

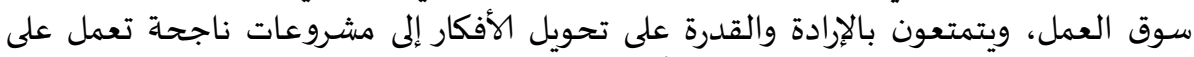

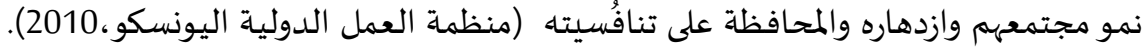

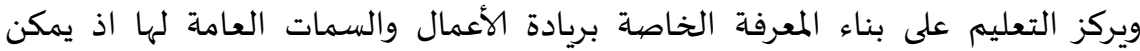

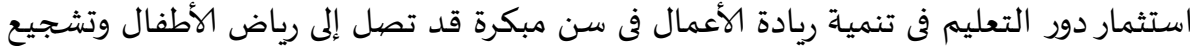

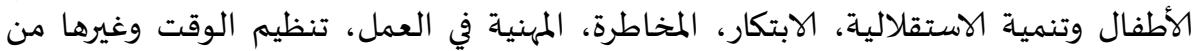
المهارات الهامة، ويمتد هذا الدور ليصل الهي المراحل المتقدمة من المارية التعليم (الشميرى والمبيريك،

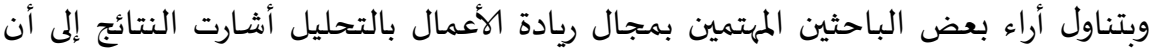

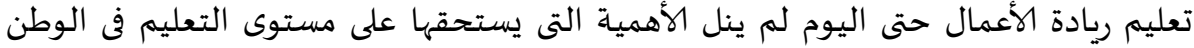

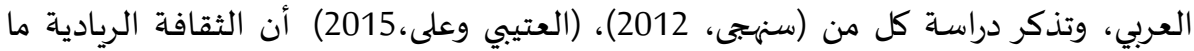

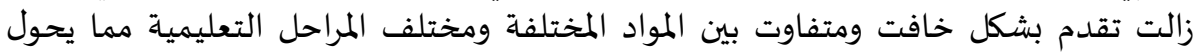
دون ارساء ثقافة ريادية صريحة موجهة لمختلف الأنشطة الصفية واللاصفية (محمود، 2017). ولكى تكون ريادة الأعمال مثمرة وذات تأثير على شخصية وقيم و اتجاهات وعادات الأفرات الفراد

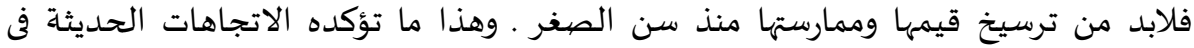

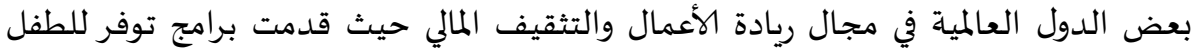

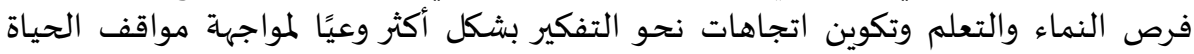

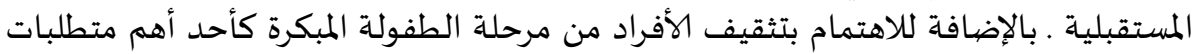

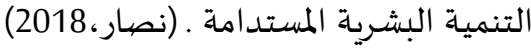

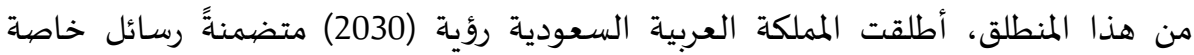

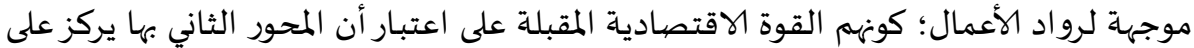

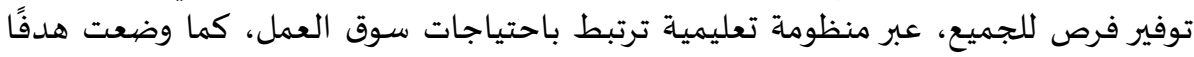

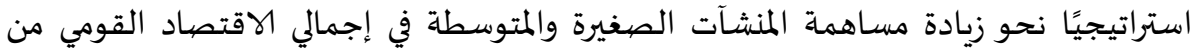
20\% إلى 35\%، وتخفيض معدئاد معدل البطالة من 11.6\% إلى \% (علواني، 2018).

لذا أصبح من الملح تفعيل دور المنهج وتصميم برامج تدعم الفكر الريادي وتحفيز الطفل

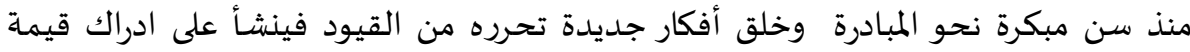




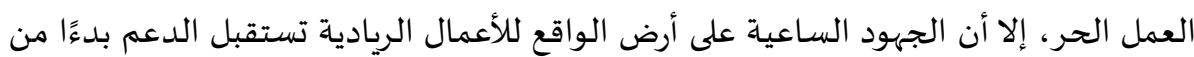

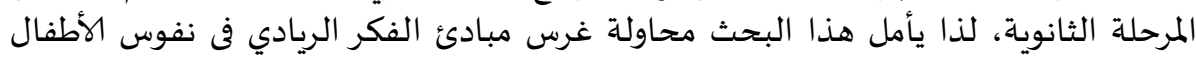

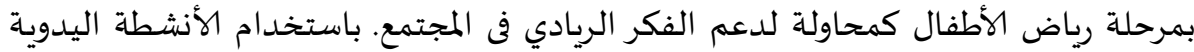

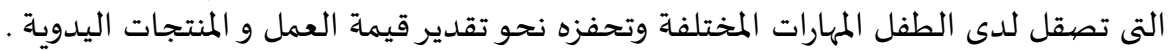
وانطلاقاً مما سبق تحددت مبررات البحث الحالي في النقاط التالية:

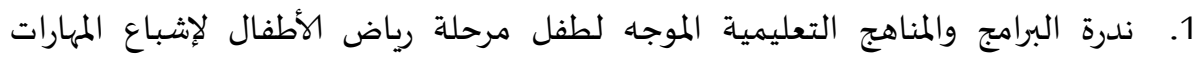

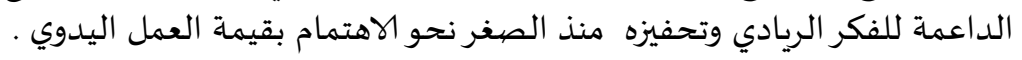
2. عزوف الباحثون عن البحث في مجال ريادة الاعمال في مجال الطفولة المبكرة.

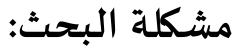

ومن هنا تنامى الإحساس بالمشكلة والحاجة إلى تنشئة أطفالنا على ممارسة المهارات الريادية

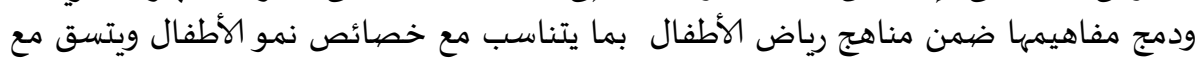

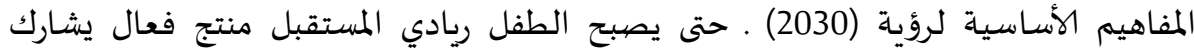
بإيجابية في نهضة مجتمعه . الماسية لرؤة وفي ضوء ما سبق تحددت مشكلة البحث في التساؤل الرئيسي التالي:-

] ما فعالية الأنشطة اليدوية في تهيئة طفل الروضة للتفكير بعقلية ريادي مستقبلي صغير ؟

$$
\text { ويتفرع من التساؤل الرئيس التساؤلات الآتية:- }
$$

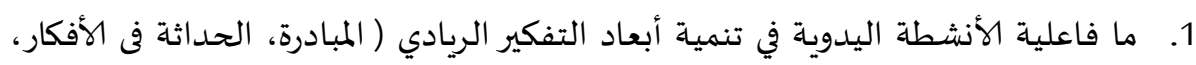

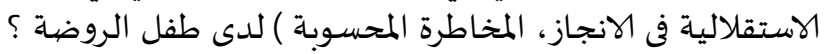

2. ما تأثير برنامج الأنشطة اليدوية في تهئية طفل الروضة للتفكير بعقلية ريادي مستقبلي صغير ؟ مأير برنا

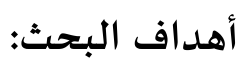
1. الكشف عن فعالية الأنشطة اليدوية في تهيئة طفل الروضة لتفكير بعقلية ريادي 2. إعداد الأنشطة اليدوية القائمة على المفاهيم المرتبطة بريادة الأعمال وأبعاد التفكير

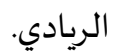
3. بناء بطاقة ملاحظة للكشف عن مدى قدرة طفل الروضة للمعالجة اليدوية للأشياء

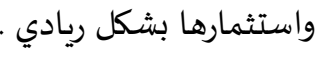


تتركز أهمية البحث في محورين:-

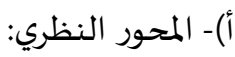

1. اكتسب البحث الحالي أهميته من حيوية وحداثة الموضوع حيث يتناول موضوع ريادة

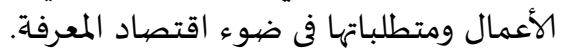

2. يركز البحث الحالي على توظيف رؤية المملكة العربية السعودية (2030) لازدهار الاقتصاد القومي.

3. توجيه الانتباه لفتح المجال أمام دراسات أخرى في ميدان ريادة الأعمال لطفل مرحلة الطفولة المبكرة.

ب)- المحور العملي: يفيد نتائج البحث الحالي الفئات التالية: 1. الطفل نفسه حيث غرس مبادئ ريادة الأعمال وتنشئة الطفل علي العقلية الريادية

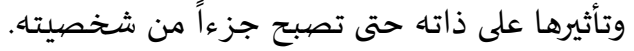

2. التربويون والعاملون علي العملية التربوية ومعدي البرامج والمناهج التعليمية في التعرف

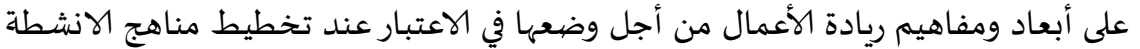
المقدمة لطفل الروضاد ومفاهيم

3. معلمات الطفولة المبكرة وذلك بتقديم دليل المعلم يشتمل على معرفة متكاملة بمفاهيم

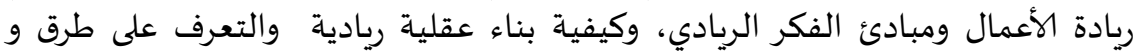
استراتيجيات تقديمها للأطفال.

4. أولياء الأمور وذلك بعرض أساليب التنشئة المناسبة لتدريب الصغار على مهارات أكثر

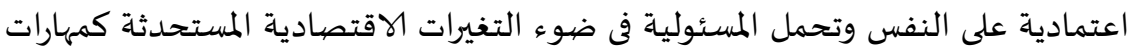

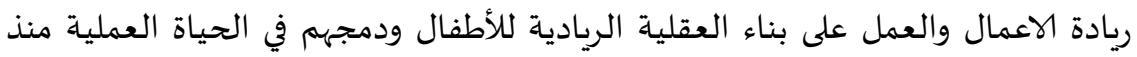
الصغر.

5. معدي برامج الأطفال في القنوات المتخصصية وحثهم على تقديم نماذج لرواد أعمال نجحوا

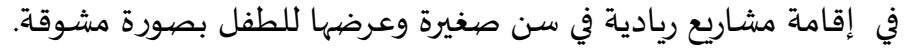
حدود البتحث:

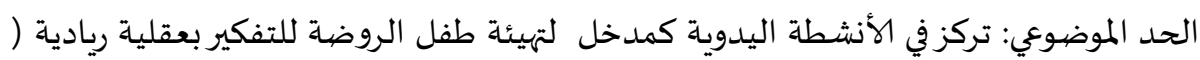

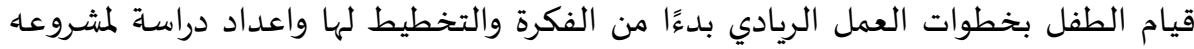

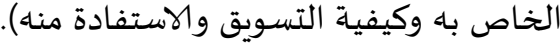
الحد الجغرافي: تم تطبيق البحث في الروضة الثانية بمحافظة صبيا . 
الحد البشري: تم تطبيق البحث على أطفال المستوى الثاني من الروضاة (30) طفلًا، والتي

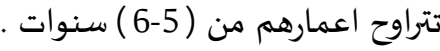
الحد الزمنى: تم تطبيق البحث خلال الفصل الدراسى الثاني بالعام الدراسي 1441هـ

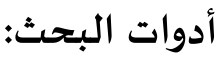

1. إعداد بطاقة ملاحظة للكشف عن مدى قدرة طفل الروضة للمعالجة اليدوية للأشياء واستثمارها وتناولها بعقلية ريادي (إعداد الباحثات لمدات).

2. إعداد برنامج الأنشطة اليدوية لتفعيل أبعاد التفكير بعقلية ريادي( مشاريع صغيرة

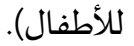

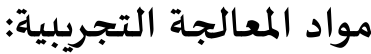

برنامج الأنشطة اليدوية فى تهيئة طفل الروضة للتفكير التحبية بعقلية ريادي مستقبلي صغير. واستخدم البحث الحالي المنهج شبه التجريبي القائم على ( التصيميم التجريبي ذوائل العيدة العينة

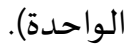

$$
\text { فروض البحث: }
$$

1. توجد فروق دلالة احصائية بين متوسطات درجات الأطفال في القياس القبلي والبعدي لبطاقة ملاحظة تفكير الطفل بعقلية ريادية وأبعادها ( المبادأة، و الحداثة الحاثة في الأفكار،

$$
\begin{aligned}
& \text { الاستقلالية في الانجاز، لاحكاز } \\
& \text { و المخاطرة المحسوبة) }
\end{aligned}
$$

2. يوجد تأثير فعال لبرنامج الأنشطة اليدوية المستخدم كمدخل لتهيئة طفل الروضة للتفكير بعقلية ريادي مستقبلي صغير.

$$
\text { مصطلحات البحث: }
$$

الأنشطة اليدوية ( Manual activities):

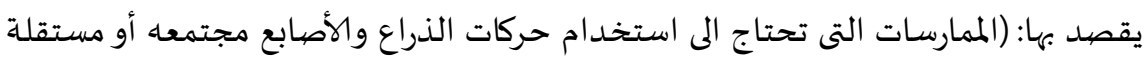
بعضها مع البعض وتتسم هذه الممارسات بالسرعال المارية والدقة في أدائها بالكفاءة والخبرة ).

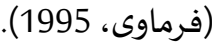

كما تعرف: بأها القدرة على تناول الأشياء الدقيقة وغير الدقيقة نسبيًا باليد او الذراع أو أو المباء

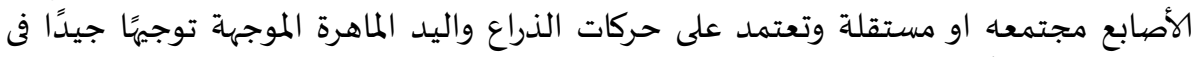

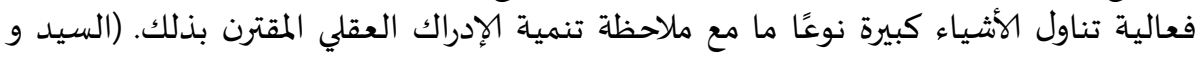

$$
\text { إبراهيم، فعالية تناول } 2010 \text { ). }
$$

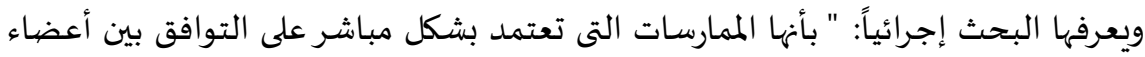

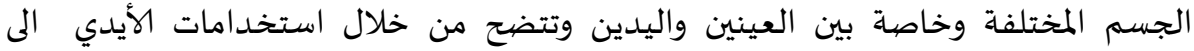

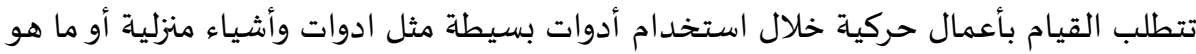


متوفر في بيئة الطفل . والأنشطة اليدوية متعددة منها الطهى، الزراعة، الفنون، إصلاحات

مفهوم ريادة الأعمال (Entreprenr ship)

هي القدرة على خلق وبناء الأشياء أي المبادرة والبناء والعمل لانجاز بناء المششروع والقدرة

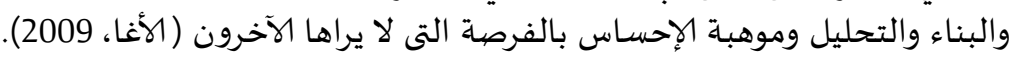

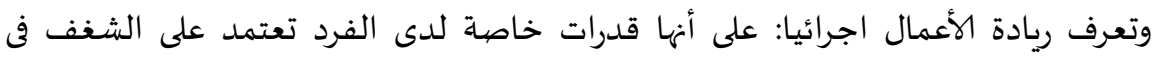

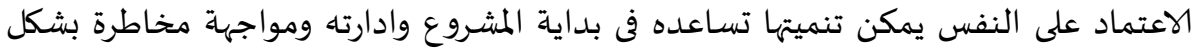

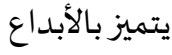

التفكير الريادي (Entrepreneurial thinking):

يرى كل من (2012،Haidar,J.L ) و (2006،kevan,Richard,W أن التفكير الريادي هو توجه

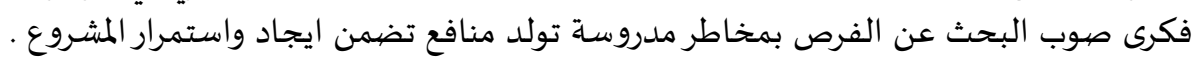

العقلية الريادية للطفل (The entrepreneurial mindset):

العقلية الريادية للطفل هي زيادة اهتمام الأطفال بأسئلة " لماذا " وممارسة الألغاز بشكل مستمر الماريه

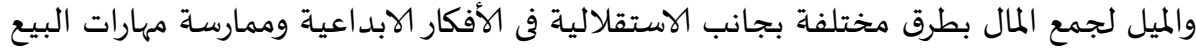

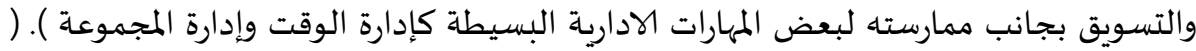

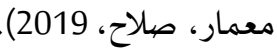

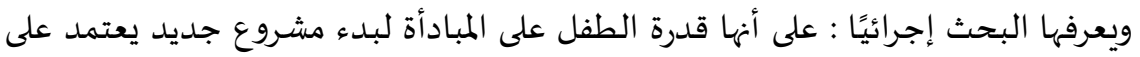

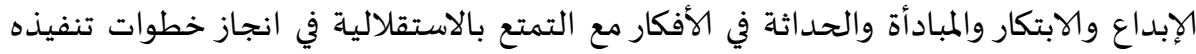

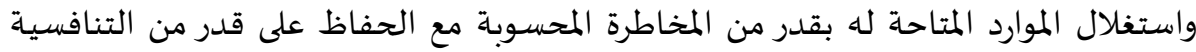

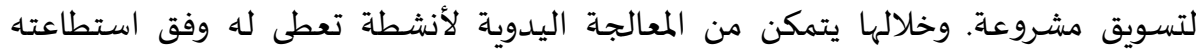

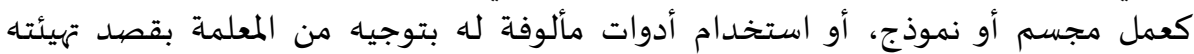

للتفكير بعقلية ريادية.

طفل الروضية (Kindergarten child):-

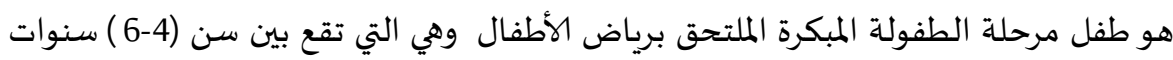

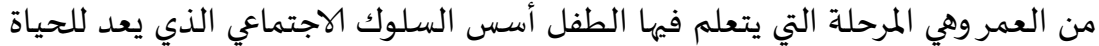

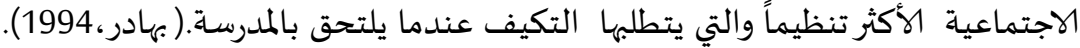




\section{إجراءات البتحث:}

في ضوء مشكلة الدراسة وفروضها تم الاطلاع على بعض المراجع المتخصصية والدراسات

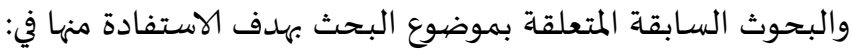

1. إعداد الإطار النظري وتحديد مشكلة البحث وفروضها.

$$
\text { 2. إعداد أدوات البحث طبقاً لأهدافه: }
$$

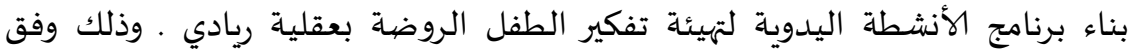

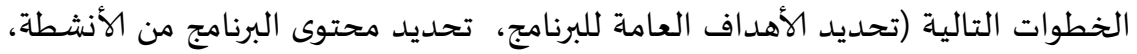

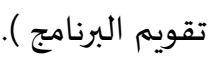

- اعداد بطاقة الملاحظة (تحديد أهدافها، أبعادها، ا تحديد التعليمات وطريقة التصحيح

$$
\text { وضبطها وعرضها على المحكمين). }
$$

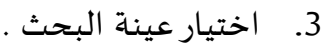

4. تطبيق أدوات البحث قبلياً على أطفال العينة التجريبية . 5. تطبيق برنامج الأنشطة اليدوية على الأطفال .

6. تطبيق أدوات البحث بعدياً على أطفال العينة التجرببية .

7. جمع البيانات ومعالجتها إحصائيًا ومناقشة النتائج وتفسيرها.

$$
\text { 8. وضع توصيات البحث ومقترحاته في ضوء نتائج البحث. }
$$

الاطار النظري و الدراسـات السابقة:

تم تناول المفاهيم الأساسية التي تناولتها الدراسة بالبحث والاطلاع حيث تبلور الاطار

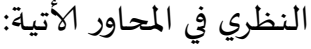

\section{المحور الأول: التربية اليدوية لطفل الروضية:}

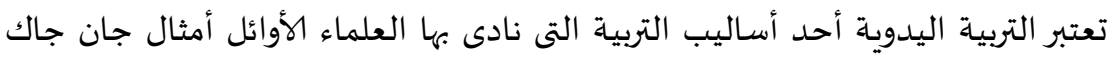

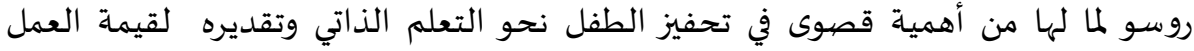

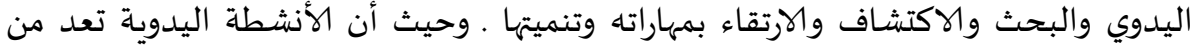

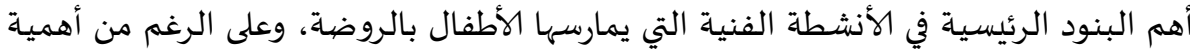

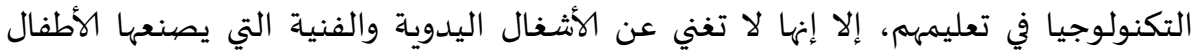

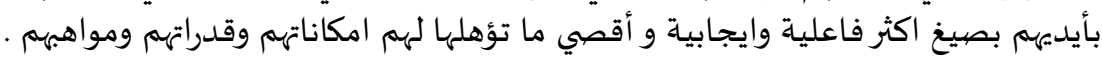

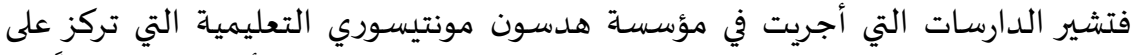

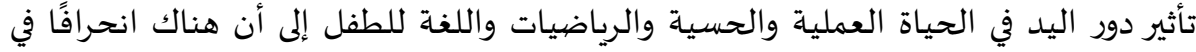

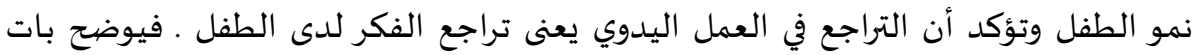
لوديك (2013) أن خلال عملية نمو الطفل لوحظ الترال الافراط في ممارسة التقنيات التكنولوجية التركية 
ومرونة اليد تجاه الآلات الالكترونية المصغرة على حساب الاقتصاد في تعليم الطفل المهارات

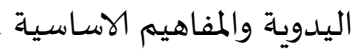

لذا ينادى المربون بضرورة بناء نظرة جديدة نحو الاعتدال في تعلم المهارات والعمل المالمبل

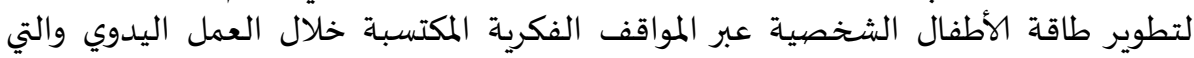

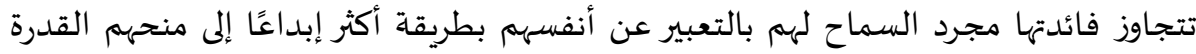

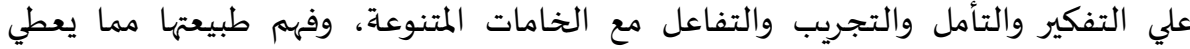

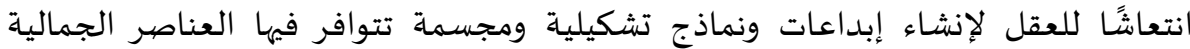
والتعبيرية. (Michaelidou, Anna2015،). لإنشاء

وتعرف الأنشطة اليدوية: بأها الممارسة باليدين فى إنجاز العمل أو النشاط الذى يحتاج

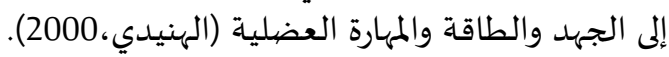

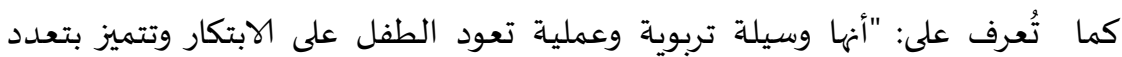

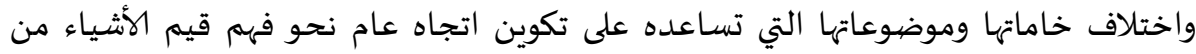

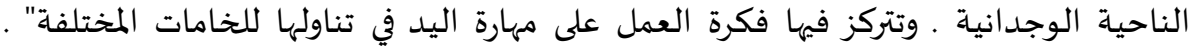

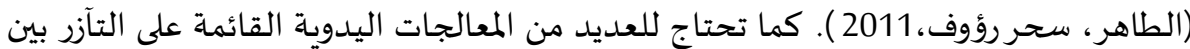

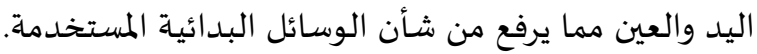

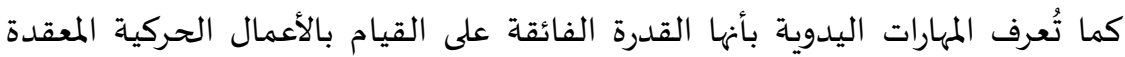

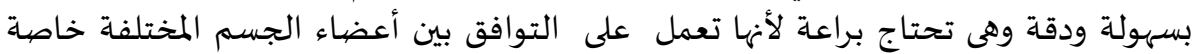

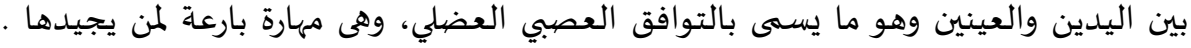
(ابراهيم، هبه كمال وآخرون، 2017).

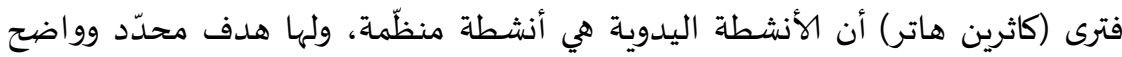

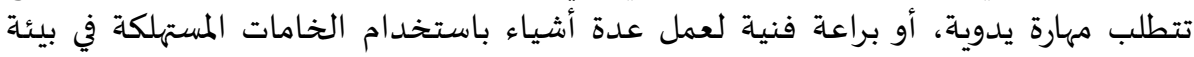

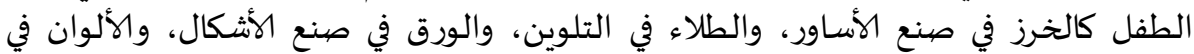

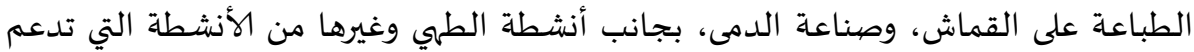

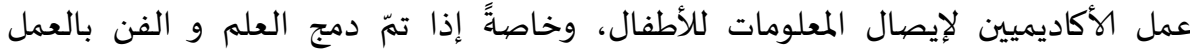

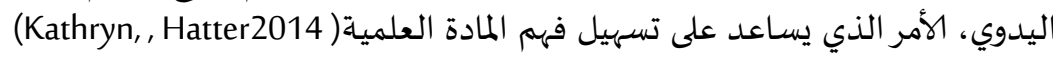

\section{أهمية الأنشطة اليدوية لطفل الروضية:}

فيذكر كاي بيكر (2013، Kay, Baker) في مقالة حول أهمية الأنشطة اليدوية في أنها تكمن في: - 20 - n

] تنمية القدرة الحركية عند الطفل: مرحلة تنطلق فيها الأداة من اليد ويزداد التطور

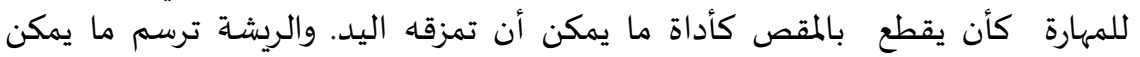
لإصبع أن ترسمه. 
[ ] تنمية القدرة التحويلية: التي يتطلب التنويع في الأدوات مما يؤدى الى التنويع في اتجاه

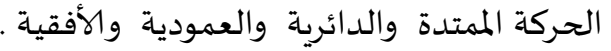

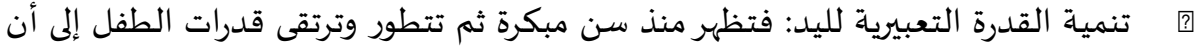

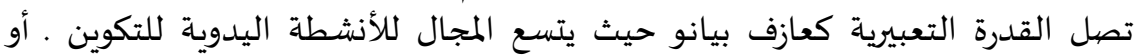

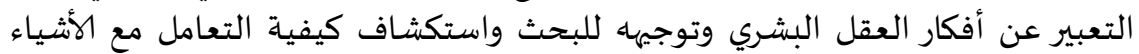

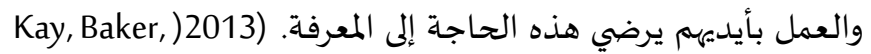

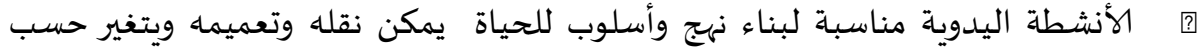
تطور الطفل ويأتي نتيجة ملامسته للأشياء والتأمل فيها . لألياء

تبني قدرات الأطفال لكيفية التصرف مع المستهلكات البيئية المحيطة بهاه وبالمحاولة والخطأ

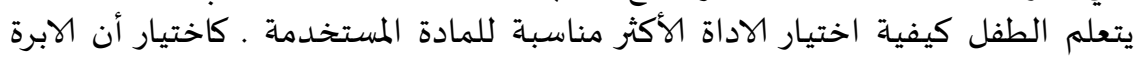

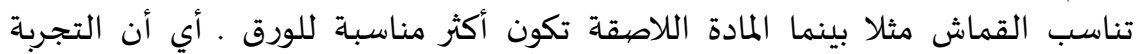

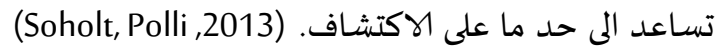

ومن المبررات القوية التى تعزز من دور الأنشطة اليدوية كأحد الاستراتيجيات الفعالة في

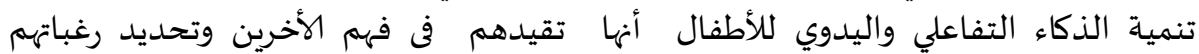

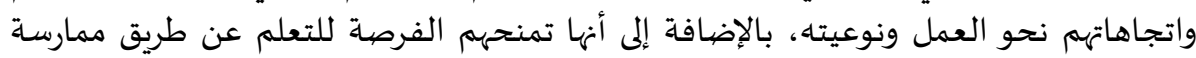

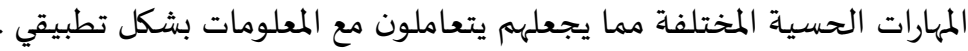
أهداف الأنشطة اليدوية للطفل:

وتذكر (شيب، نادية، 1990) في مقالها حول "الأنشطة اليدوية في المدرسة الابتدائية ".

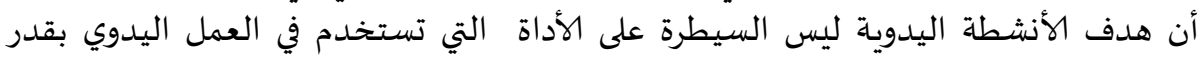
تأثيرها في تحقيق تنمية كفايات الأطفال وهى: 1. كفايات على المستوى الجسدي والنفسي وتشمل ( السيطرة على حركات الطفل، استخدام الأدوات بشكل فعال و وظيفي للكتابة والرسم ).

2. الحساسية والتوازن العاطفي في: ( أن يكون الطفل قادر على المبادأة في تصرفاته ). 3. التكيف الاجتماعي في: ( أن يتواصل الطفل مع الاخرين، ويحترم قواعد العمل اليدوي، ويشارك في الأنشطة الجماعية ).

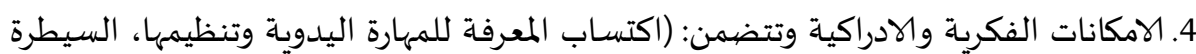
على طرق التفكير واكتساب المفاهيم مثل مفهوم الزمان و المكان، العلاقة المانة السببية) 5. تنظيم الوسائل التي يمتلكها الطفل في اكتشاف المشكلات التي يفرضها موقف ما والخطوات

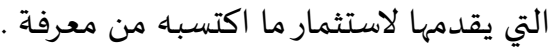

\section{مزايا الأنشطة اليدوية للأطفال:}

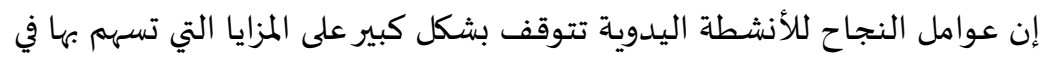
تكوين شخصية الطفل وتتلخص مزايا الأنشطة اليدوية في أنها: 
1. تصقل المهارات الحركية الدقيقة للطفل وتحسن من قدرتهم على التحكم في النشاطات

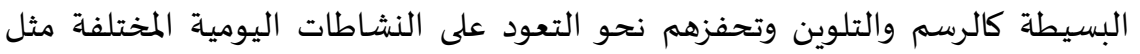
ارتداء الملابس والاستحمام وربط حبال والتونم الأحذية وغيرها.

2. تشجع الطفل على بناء ذاته فيتعلم كيف يشعر بالرضا عن نفساه مما يولد لديه الطاقة الإيجابية ومشاعر التقبل للتعلم والانجاز.

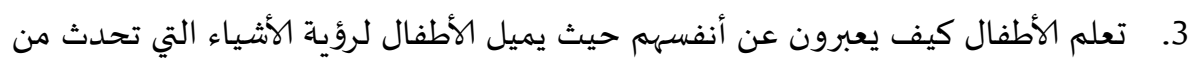

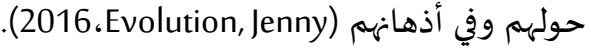

4. تعزز القدرات البصرية للطفل و ذلك بتشجيع الحس الإبداعي لديه من خلال ملاحظة

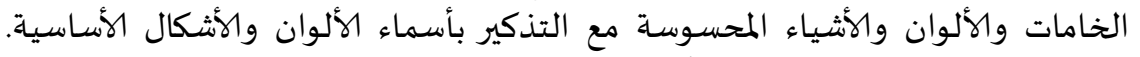

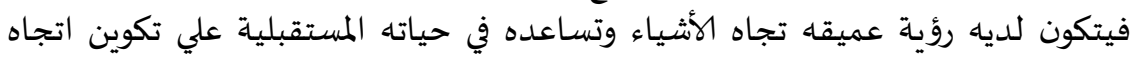

الذوق العام. (Reeves, Stephen, 2017)

5. تنهى القدرات العقلية للأطفال كالتفكير واتخاذ القرار وحل المشكلات والتحات و مهارات الأداء

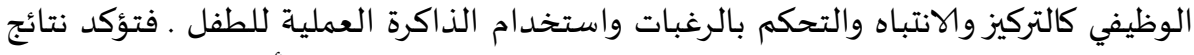

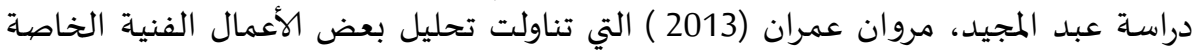

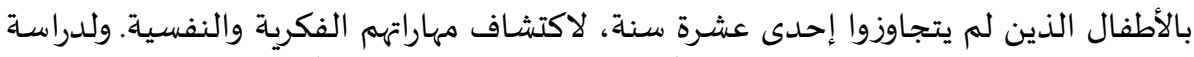

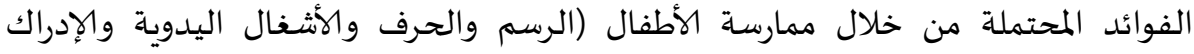

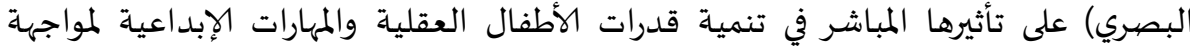

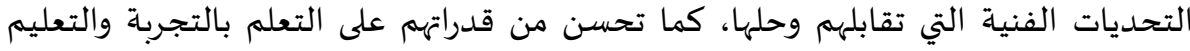

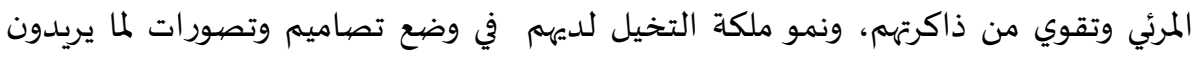
تنفيذه. (عبد المجيد، مروان عمران، ونمون 2013).

\section{المبادئ الأسساسية لتنمية المهارات اليدوية عند الطفل:}

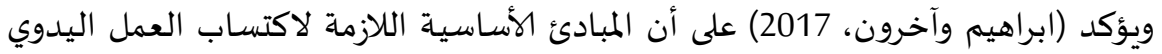

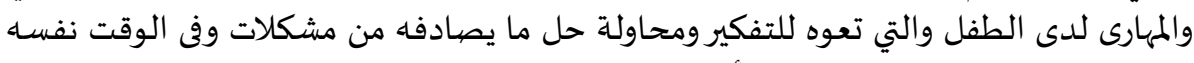

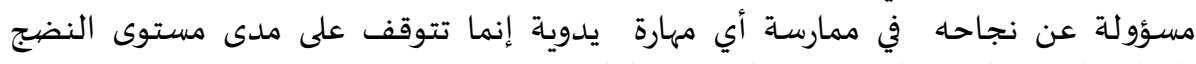
المتطلب لتعلم المهارة والتعامل مع الخاماه في معات المطلوبة. 1. لذا يتطلب في البداية أن يجرب بنفساه في أكثر من مجال حتى يكتشف المهارة التي يحبها ثم يبدأ فيتعلمها.

2. يتعرف الطفل على الحركات المتضمنة بالمهارة وتدريبه على طرق أدائها عمليا.

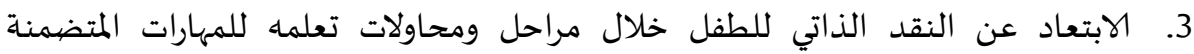

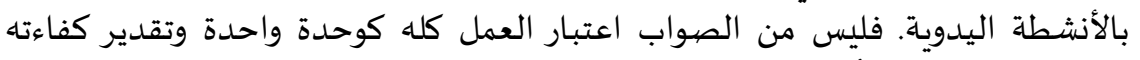

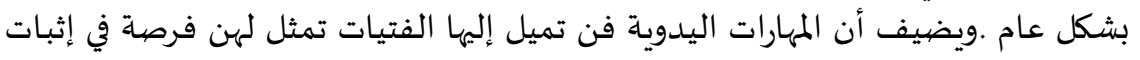
الذات و يلزمها الدقة والابتكار. 


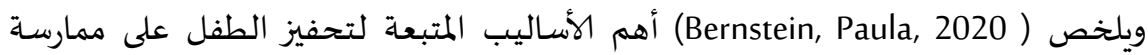

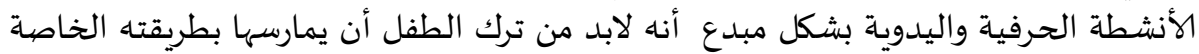

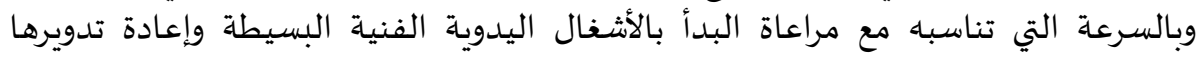

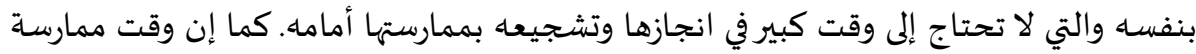

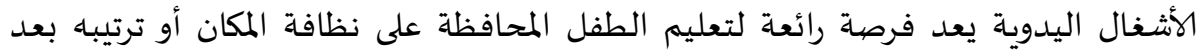

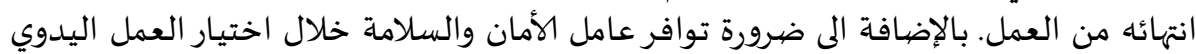

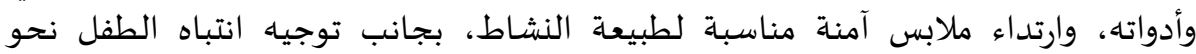

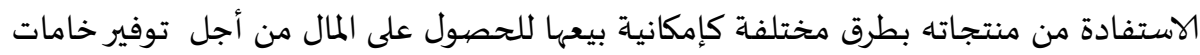

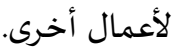

ويعرض (Stephen\& et al، 2018) في بحثه حول الذكاء اليدوي في العملية التعليمية المقدم التمان

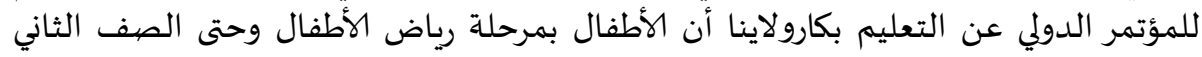

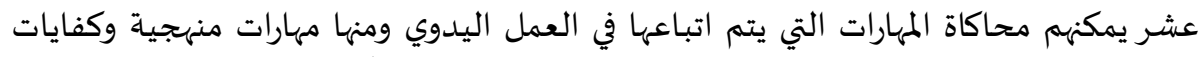

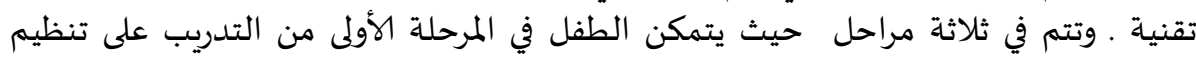

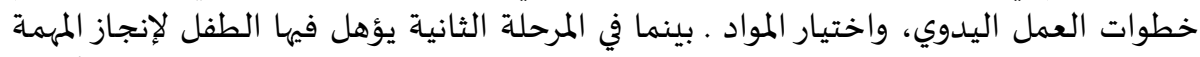

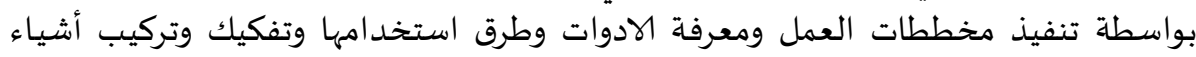

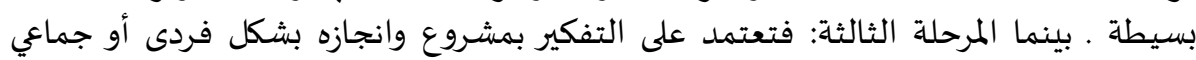

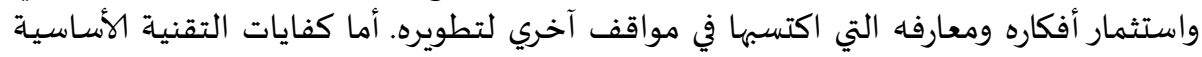

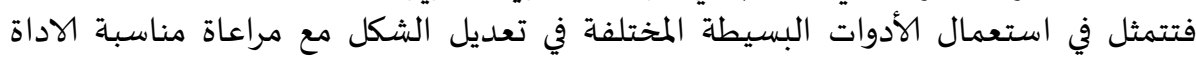

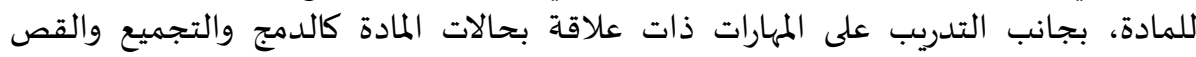

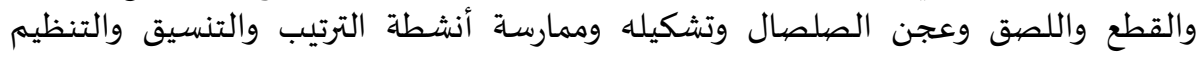
لإنجاز العرائس والألعاب الصغيرة الصيال

\section{الأنشطة اليدوية وعقلية طفل الروضية:}

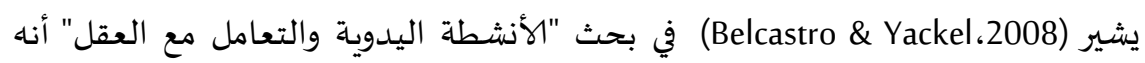

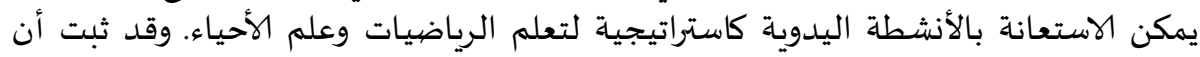

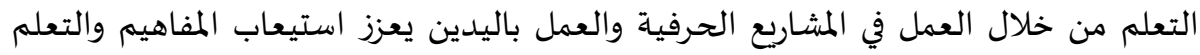

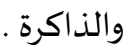

ويوضح ( Thorstinsson, G, 2012 في دراسته حول الذكاء اليدوي "أساس تعليم الحرف الذهاء

اليدوية" إن الانشطة اليدوية تساهم في نمو الذكاء العملي وهذا ما يقتنع باه معظم الماء المربين .

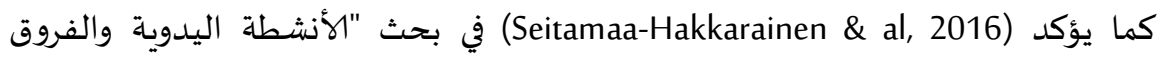

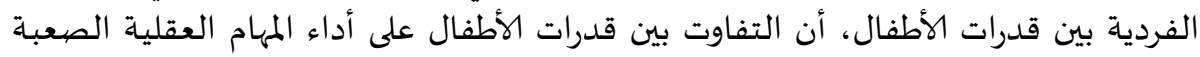

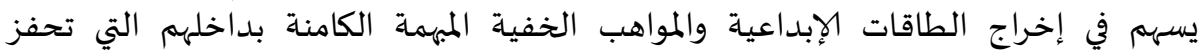

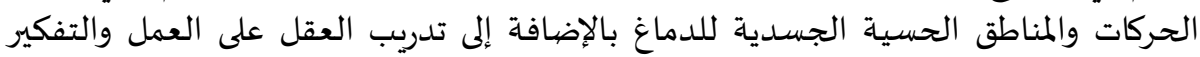

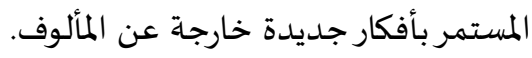




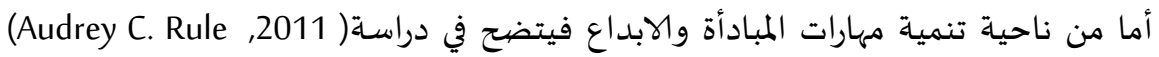

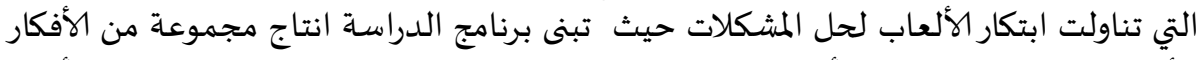

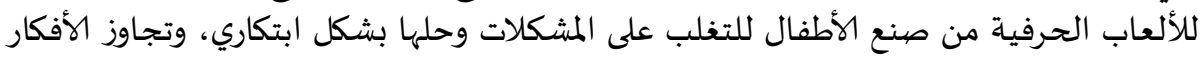

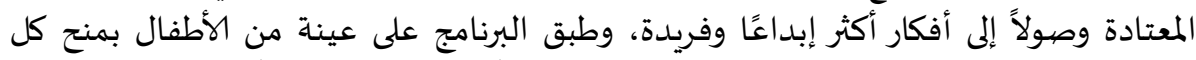

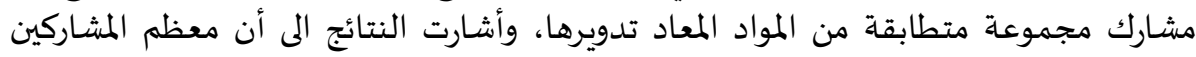

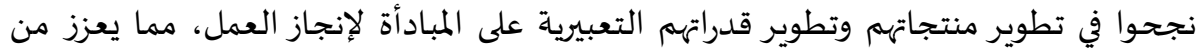

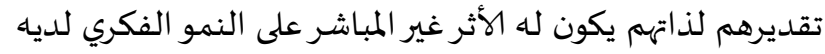

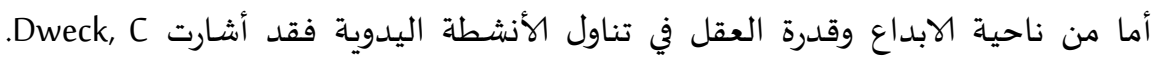

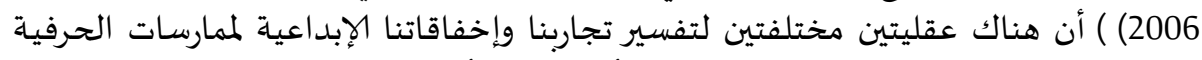

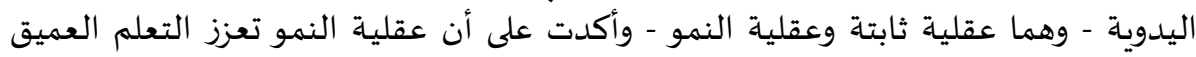

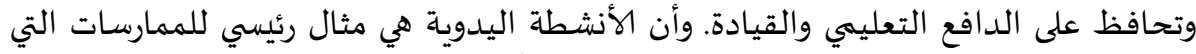

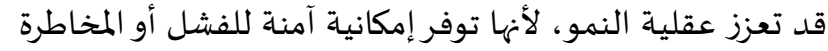

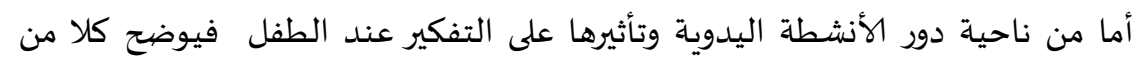
(Groth ,Camilla \& etal,2018)

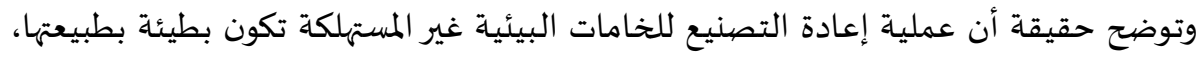

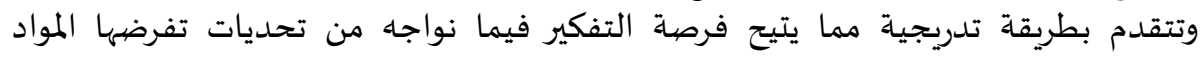

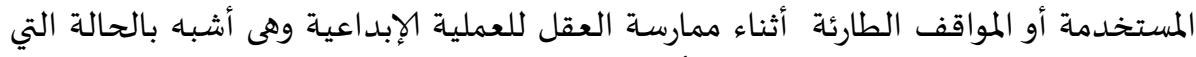
يتعايش معها الطفل خلال اللعب ويعد أمر ضروري لنمو الدمانة المعاغ في مرحلة الطفولة.

\section{المحور الثاني: بناء عقلية الطفل الريادية:

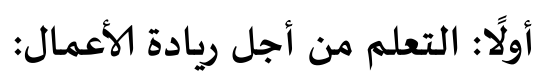

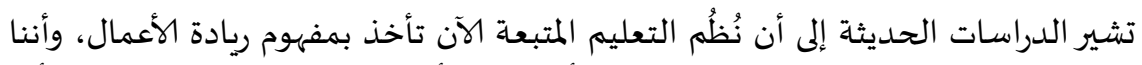

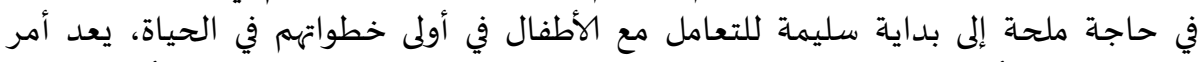

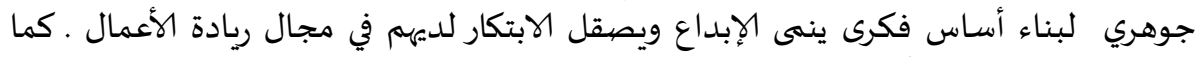

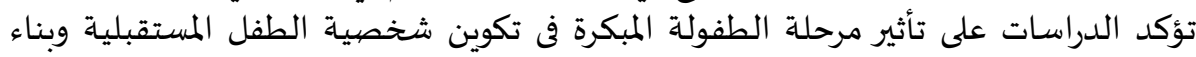

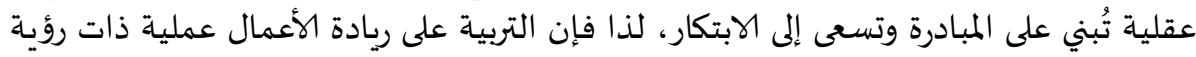

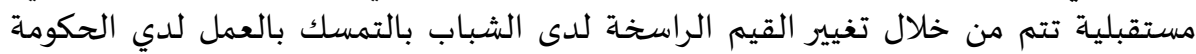

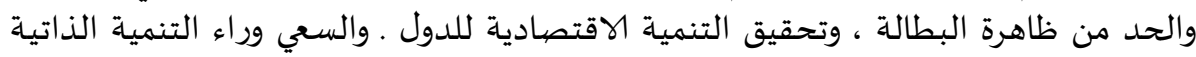

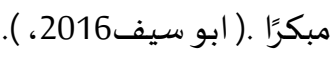

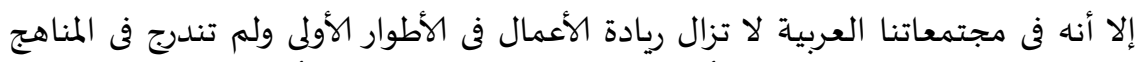

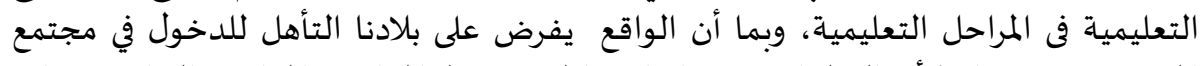

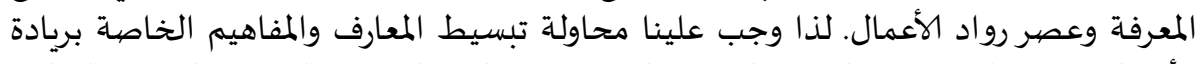

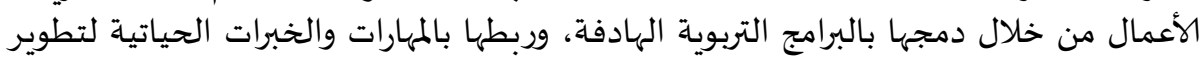

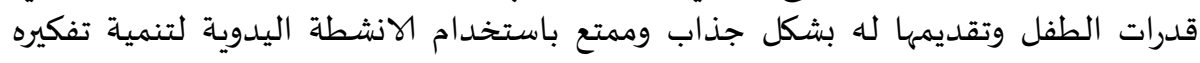


بعقلية مبنية على مهارات الفكر الريادي لتصبح ريادة الأعمال ثقافة فردية ومؤسسية

ومجتمعية.

وتعرف (زيتون، 2019) التعلم من أجل ريادة الأعمال لطفل الروضة على أنهة الآليات

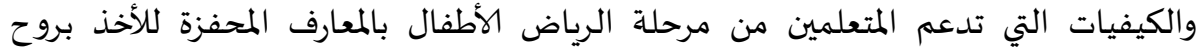

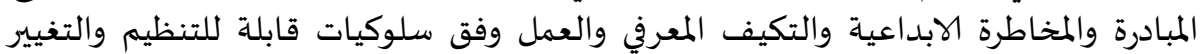

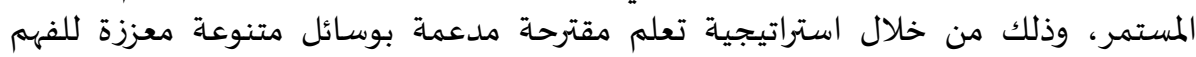

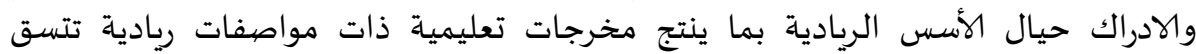

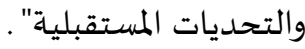

بينما تعرف التعليم الريادي للطفل: على أهها عملية احترافية ترتبط بإكساب الطفل التميز

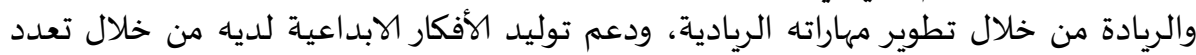

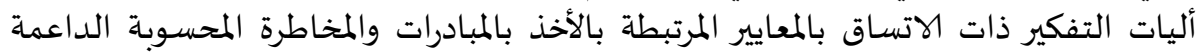
للإنجاز والتعلم ـ (زيتون، منى مصطفى، الإنسات بالمعاير المرتية بالات

\section{أهمية اكساب طفل الروضية مهارات ربادة الأعمال:}

1. اكساب الأطفال بعض المفاهيم والمعارف الأساسية للمعلومات المرتبطة بريادة الأعمال.

2. الإسهام في تنشئة وخلق جيل من الشباب قادر على انشاء مشروعات اقتصادية مطورة .

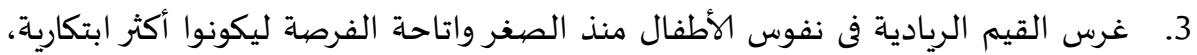
وتنمى شخصياتهم وتجعلهم أكثر ميلا نحو المبادرة والتفكير في إقامة مشاريع أكثر إيجابية.

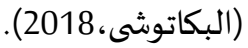

\section{أسس تحقيق ريادة الأعمال لأطفال الروضية:}

1. ضرورة اتباع الأساليب والطرق المبتكرة في التدريس لتحقيق سمات الريادية للأطفال والتي

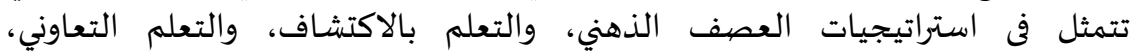

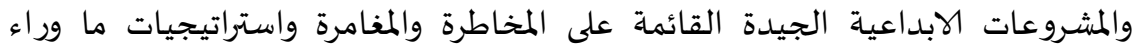

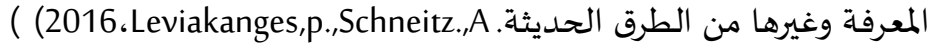

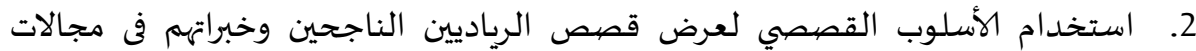

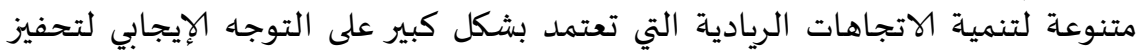

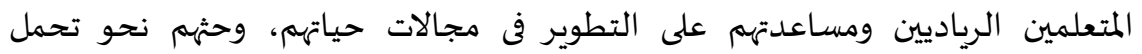

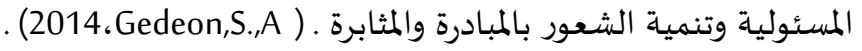

3. تنوع مهارات التفكير الريادي ومنها القدرات الابداعية، والادارة الذاتية و المخاطرة

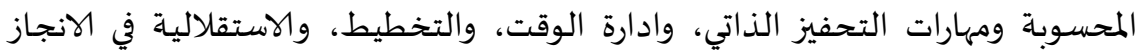

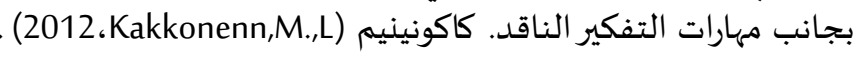

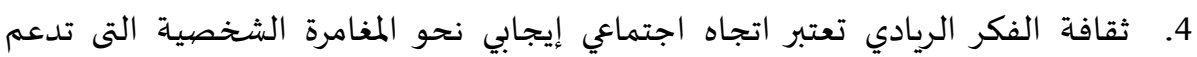

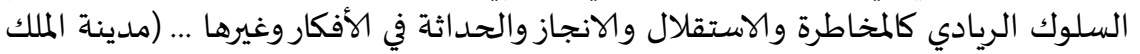
عبد العزيز للعلوم والتقنية، برنامج بادر لحاضنات والإنقال التقنية ). 


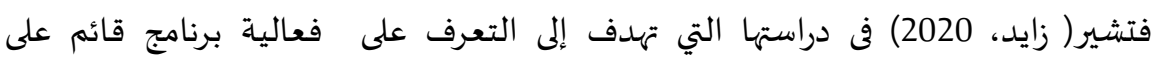

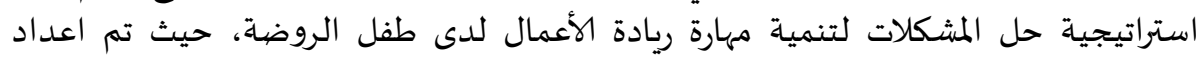

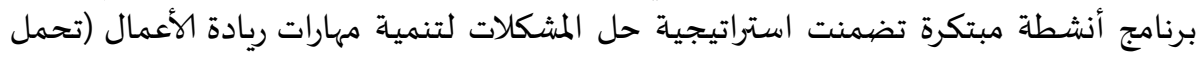

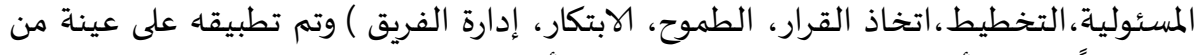

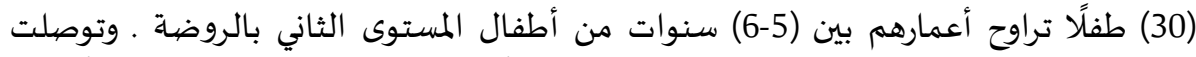

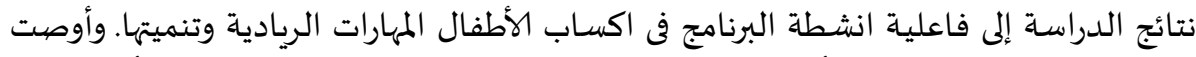

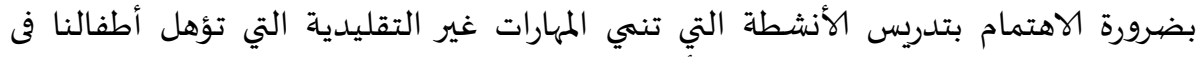

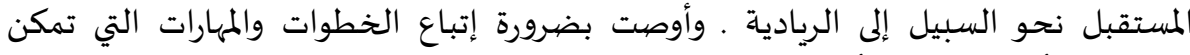

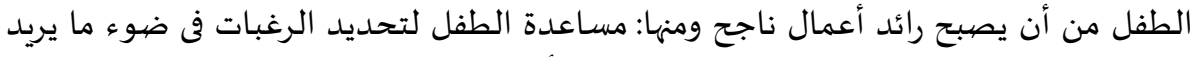

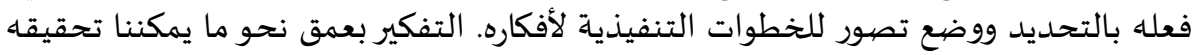

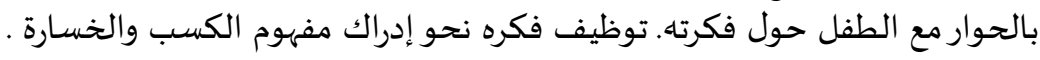
خصيائص الشخص الريادي:

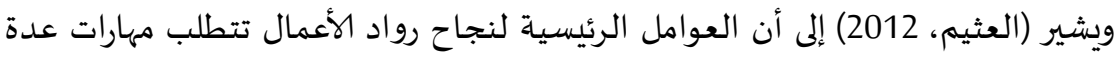

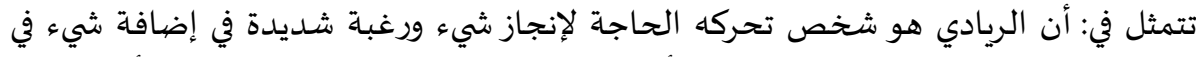

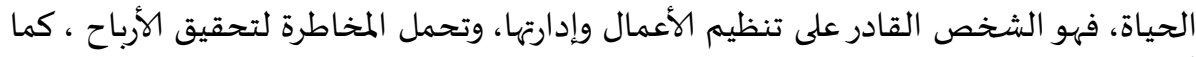

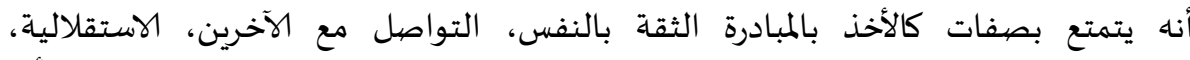

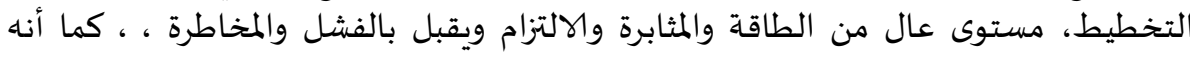

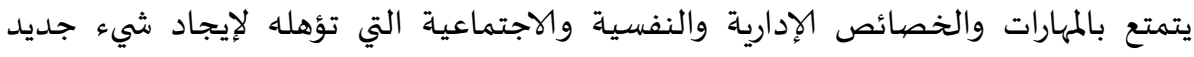

ومبدع - و بالم

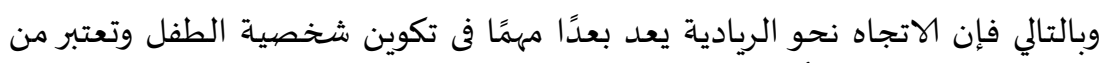

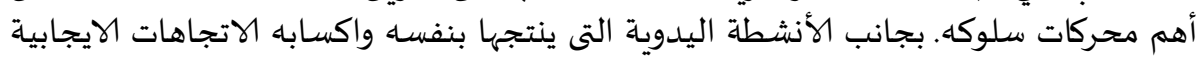

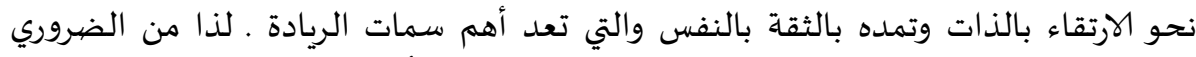

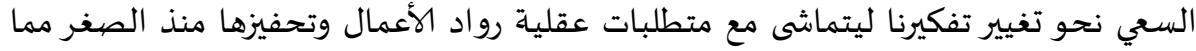

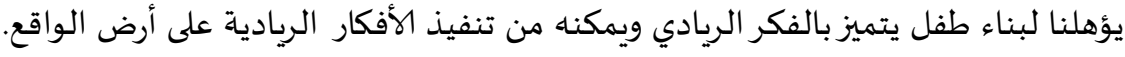

\section{ثانيًا: تفكير طفل الروضاة بعقلية ريادية :}

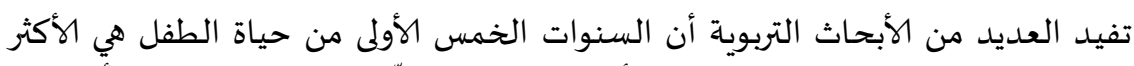

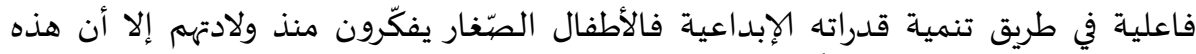

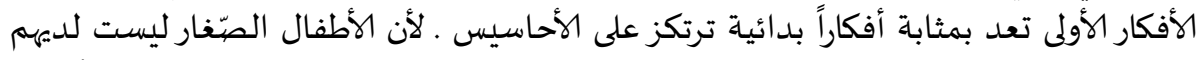

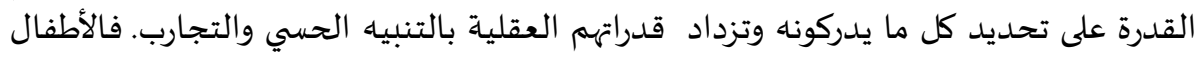

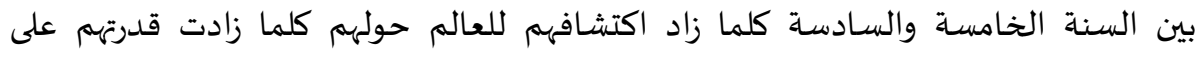

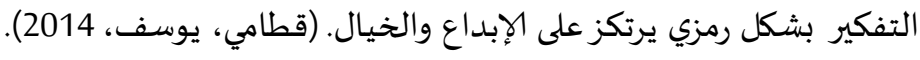


مفهوم التفكير الريادي (Pioneering thinking):

ويعرف التفكير الريادي بأنه: " القدرة على تصهيم أمر ما، أو إعطائه شكلاً او إنجازه

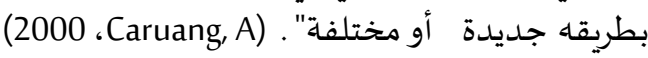

بينما يعرفه ( ا.J, 2012، Haidar)" بأنه توجه فكري صوب البحث عن البرو الفرص بمخاطر

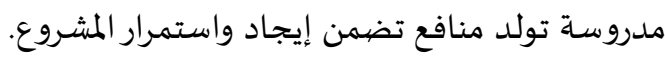

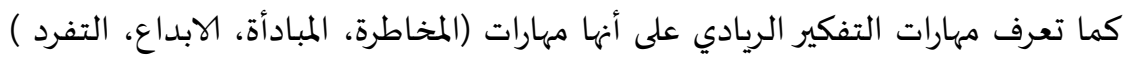

التى تساعدهم في تنفيذ بعض الأعمال المتطورة والمتميزة .( سالم، 2017)

\section{مفهوم العقلية الريادية للطفل:}

تعرف العقلية الريادية على أهها القدرة والاستعداد لخلق مشروع تجارى وادارته ومن ثم

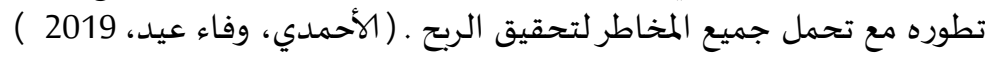

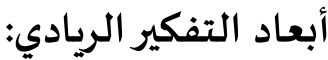

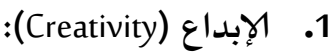

يعرف الإبداع بأنه عملية عقلية بشرية تتجه لإيجاد طرق ووسائل، وأفكار غاية في التفرد

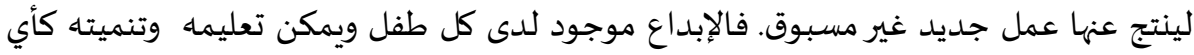

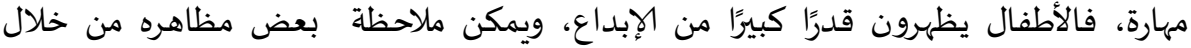

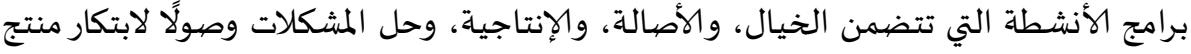

ذي قيمة. (عويس، رزان، 2009).

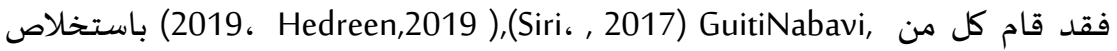

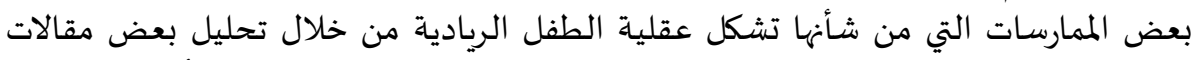

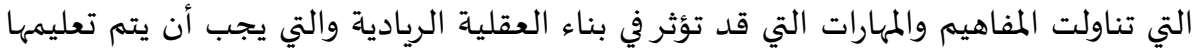

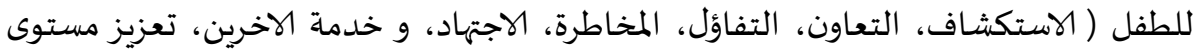

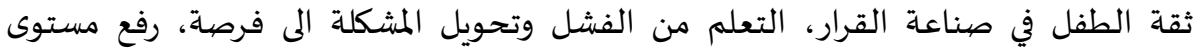

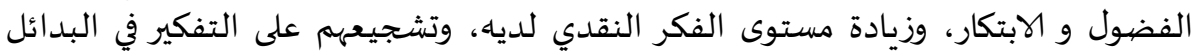

$$
\text { واقتراحها، ورفع مستوى مهارات الاتصار، وزيال) . }
$$

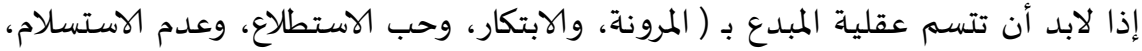

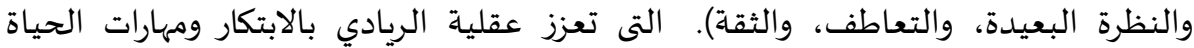

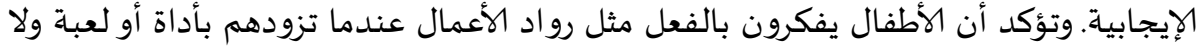

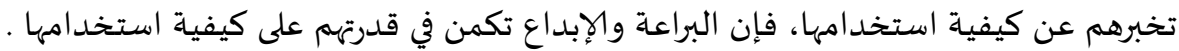

(Hedreen ,Siri ,2019)،, 2017)Guiti (Nabavi,

بينما يشير (عاكف، لطفي،2010) إلى طبيعة العلاقة بين مفهومي الإبداع والريادة بأنها

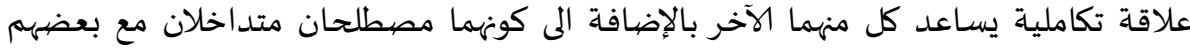
البعض . فيؤكد على أن من أهم خصائص تكامل بين الإبداع والريادة هي القيمة الإلية الابداعية 


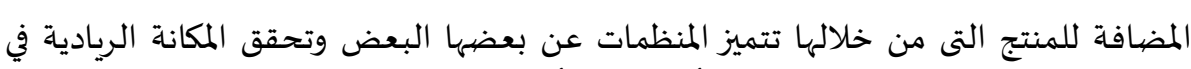

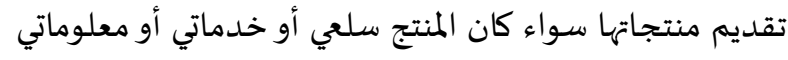
2. (Proactiveness ) : المبادأة

فيذكر (Caruang, Al,2006I) أن المبادأة وهي المشاركة في مشاكل المستقبل والحاجات

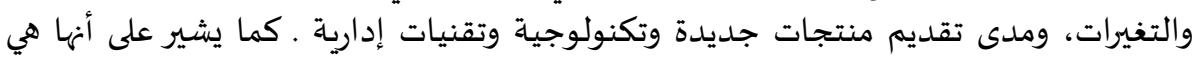

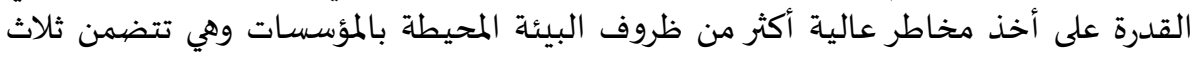

1. إقرار ملاحقة او عدم ملاحقة المنافسين بالإبداع.

2. المفاضلة بين المحاولات الحقيقية هي النمو والإبداع والتطوير .

3. محاولة التعاون مع المنافسين من أجل احتوائهم.

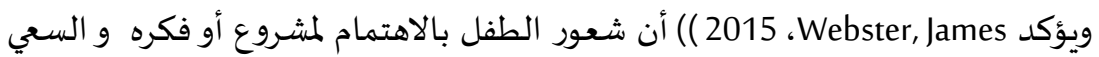

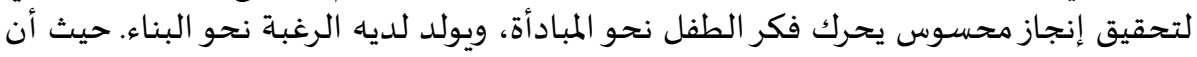

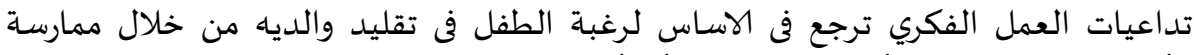

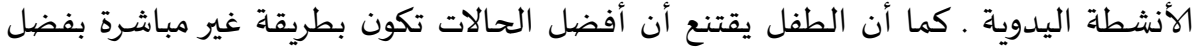
تشجيع الكبارورضاهم عما يقوم باه.

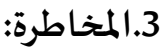

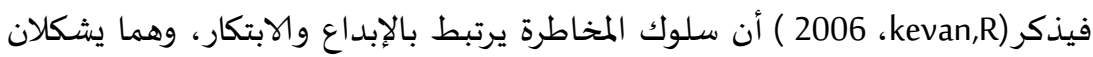

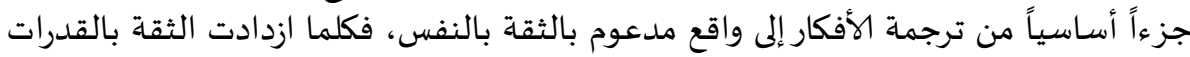

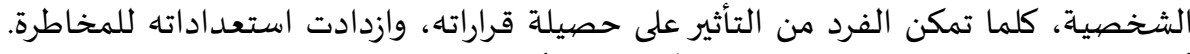

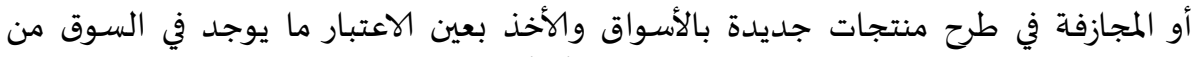

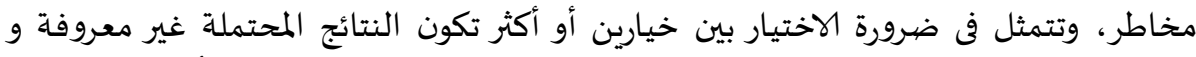

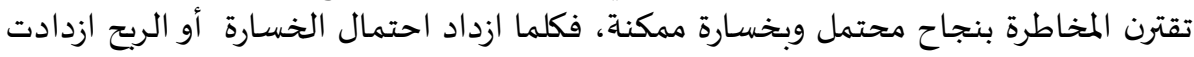

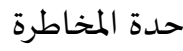

ويتم تعزيز قدرة الطفل على المخاطرة من خلال:

ت تدريبه على أن يكون لديه خطة بديلة لأي عمل يقوم به.

] تعزيز تفكيره نحو مخطط يتعلم كيف يستفيد من السلبيات ويقلل نسب المخاطرة .

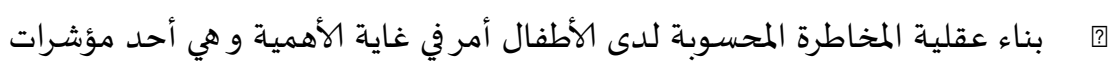
النجاح

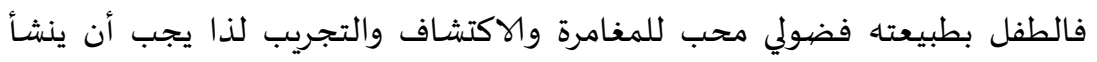

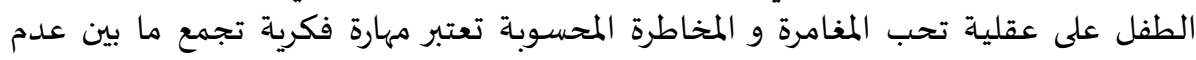




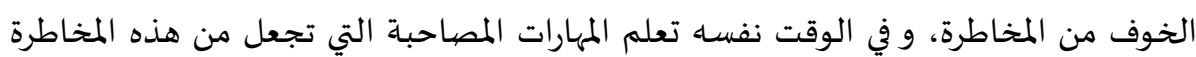

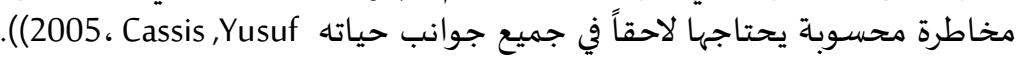

بينما يضيف (Groth2015 ،) في دراسته حول تأثير العواطف في عمليات تقييم المخاطر

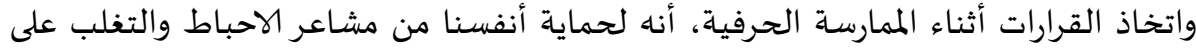

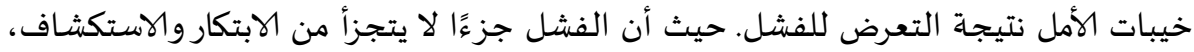

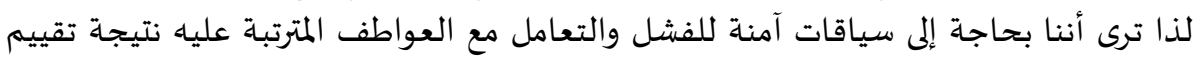

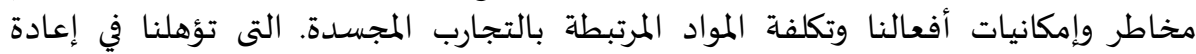

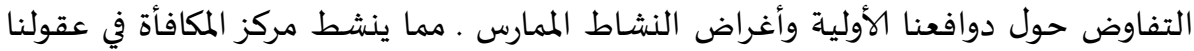

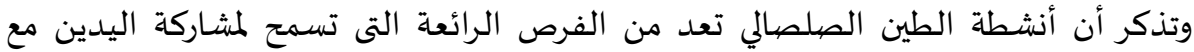

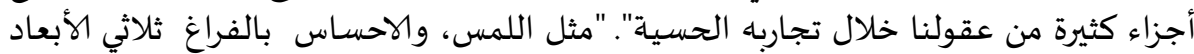

\section{مبررات الحاجة الى غرس العقلية الريادية:}

1. أن التعليم الريادي الناجح لا بد له من المزيج بين عاملين مهمين وهما الفرص الموادودودة في

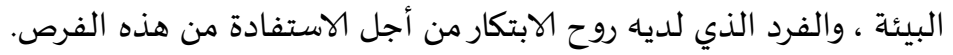

( Shane \&Venta karaman, 2000,223 ).

2. تتركز العقلية الريادية على توظيف مجموعة واسعة من السياقات الشخصية والتنظيمية بما يجعل الطلاب قادرين على الابداع ، ولديهم ثقة في مساعيه من العيهم والتكيف مع اقتصياد

$$
\text { السوق. }
$$

(Gibb, 2011, 152-153)

\section{تكوين العقلية الريادية لدى طفل الروضية فطرية أم مكتسببة:-}

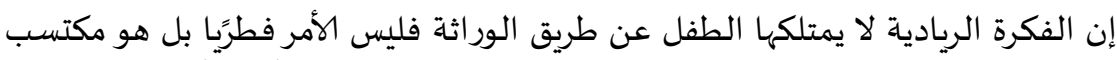

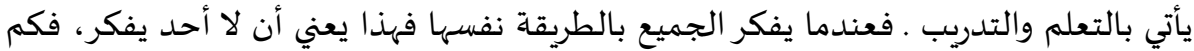

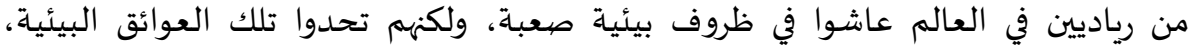

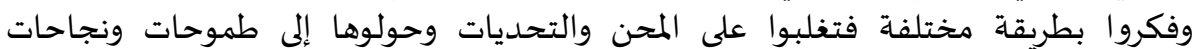

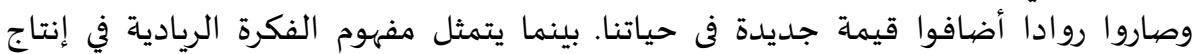

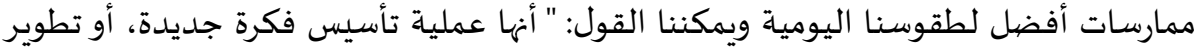

فكرة قديمة بحيث يتم تلبية احتياجات المستهدفين من خلال هذه الفكرة ". (حسين، 2013).

ويوضَّح بلال السكارنة ( 2006 ) أن من أهم العوامل في نجاح عقلية الريادي الصغير هي الرئي

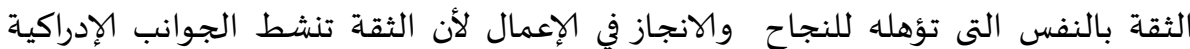

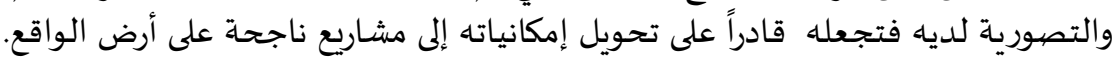

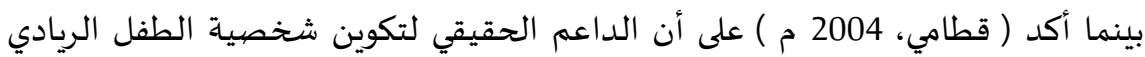

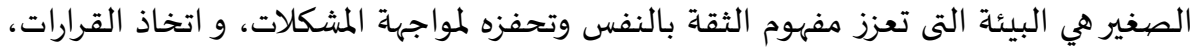

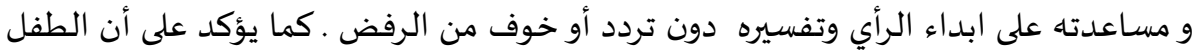


إذا أعطي الفرصة بأن يعمل في مجال يحبه و يتحكم في وقته و عمله، فسوف يخلق هذا فيه شخصاً مميزاً يحقق أهدافاً تعود عليه.

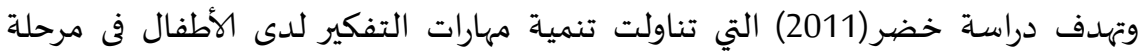

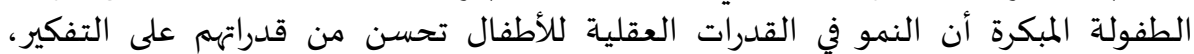

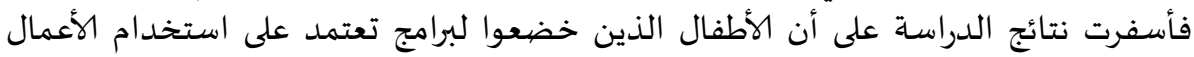

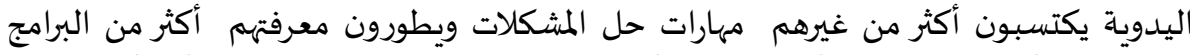

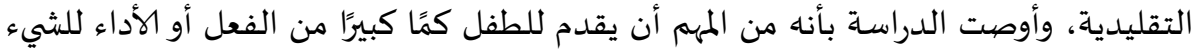

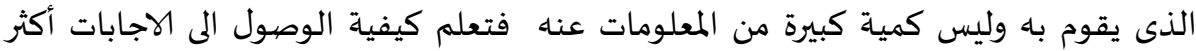
أهمية من الاجابات نفسها ـ (خضر، نجوي كيرة من المعلوماتر،2011)

\section{تنمية مهارات العقلية الريادية لأطفال:}

فتوضح (Jodie, Cook, 2010) في مقالها حول "كيفية تربية الأطفال الرياديين على تصميم نمط الحياة. أن تنمية مهارات العقلية الريادية للطفل وتمكينه من ممارستها يتطلب: 1. تطوير اتجاه الطفل نحو كيفية رؤيته لقدراته الخاصة وما هي مكانته في المستقبل، وكيف

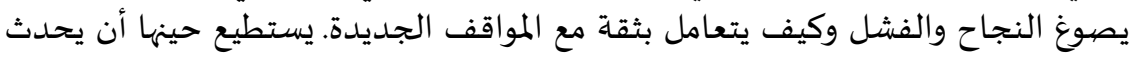
تغيير إيجابي ذي قيمة.

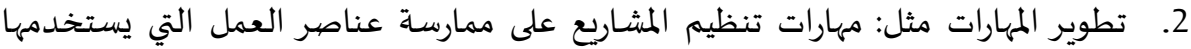

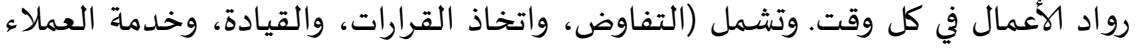

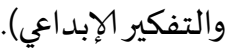

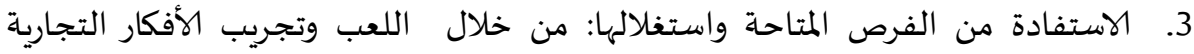

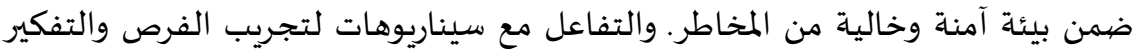
بعقلية الاحتمال فتصبح أدمغتهم مدربة على البحث عن المناطية الفرص

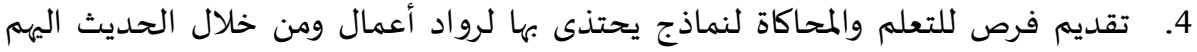

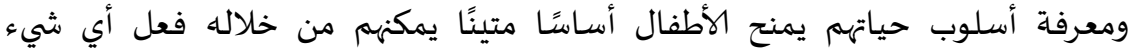

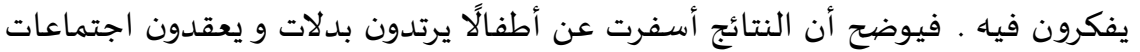

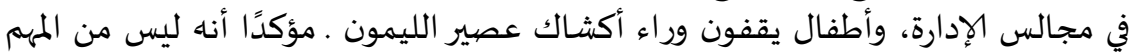

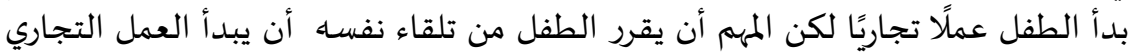

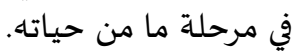

\section{استراتيجيات تدريس الطفل التفكير بعقلية ريادية:}

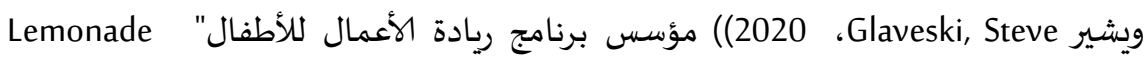

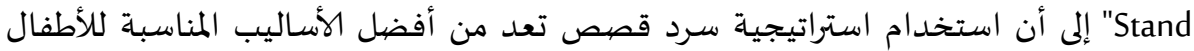

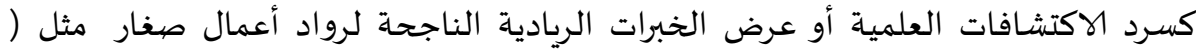

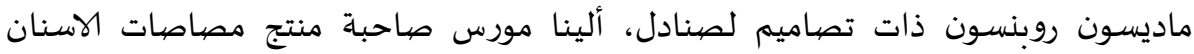


بنكهات عضوية ....) وغيرها من المبادرات التى من شأهها أن تحفز فكر الطفل نحو إنتان إنتاج الأفكار

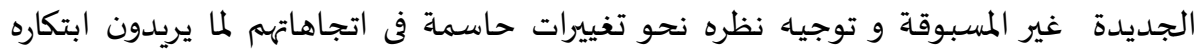
عندما يكبرون، وليس ما يريدون أن يكونوا عليه في المستقبل.

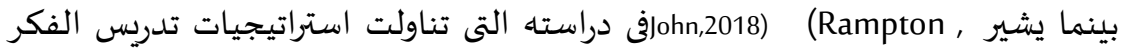

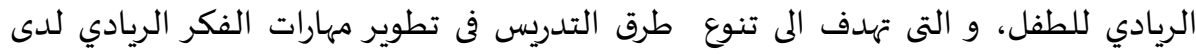

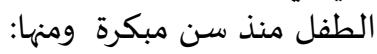

.اجابة عن تساؤلات الطفل حول الفكرة الوليدة يساعده على بلورة الفكرة لديه .

2. تدريب الطفل على التأمل في التفاصيل الدقيقة لما يحيط به قد يلهماه بفكرة.

3. تنشيط تفكير الطفل ومعلوماته باستخدام مهارة العصف الذهنى لتجعله أكثر حماسًا. 4. التدرببات الذهنية ومناقشة الطفل وتحليل كل يستمع اليه أو يقرأه ممكن أن يولد لديه

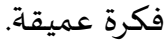

5. مساعدة الطفل في تسجيل الأفكار كما يتصورها.

لمحات تربوية في رعاية الطفل الريادي:-

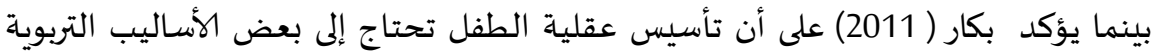

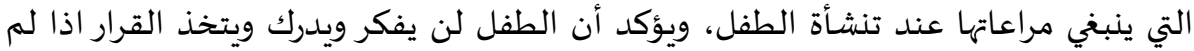

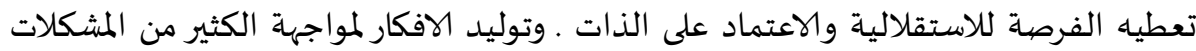

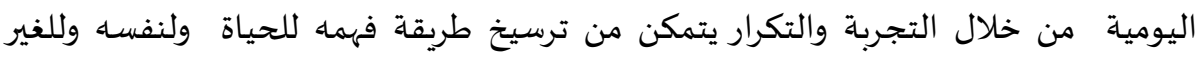

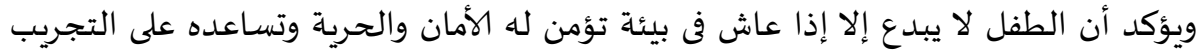

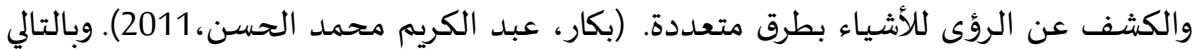

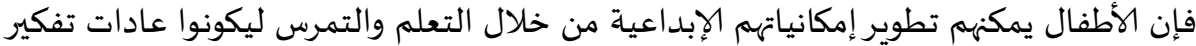
أكثر إبداعاً.

وتشير (غيبة، وفاء أحمد، إنها، 2017) بالرغم من كون الأسرة هي المعلم الأول في بداية حياة

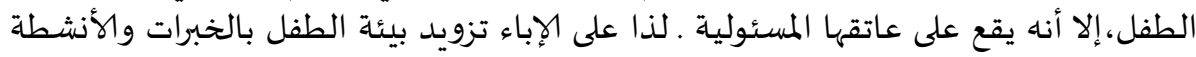

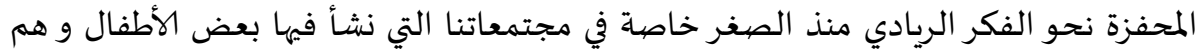

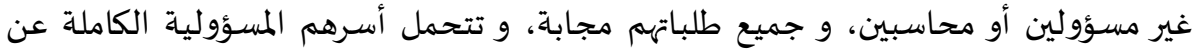

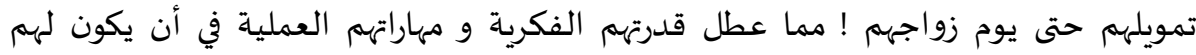
شخصية مستقلة لذا يتطلب مراعاة الآتي:

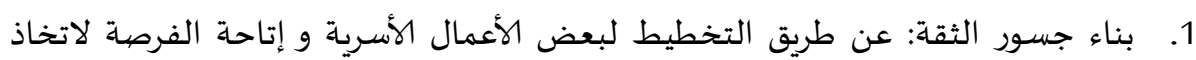
القرارات التي تجعله يشعر بمدى أهمية و قيمة تفكيره. 2. اللقب الإيجابي: مما يشعره بتميزه مثل ( نبيه / عبقرينو / الماهر / الخ ) ). 3. معرض لمنتجات الطفل: من وسائل التعزيزو التشجيع و الاحتفاء بالطفل و بإنتاجه . 
4. المشكلة و حلها: تبرز روح التحدي لدى الطفل و تجعله يخرج ما عنده من طاقات و أفكار

مبتكره و حلول.

5. الضبط السلوكي لأن الشخصية الريادية ليست مخزية و لكنها تسعى للاكتشاف لذا لذا

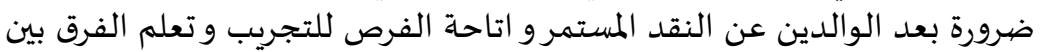

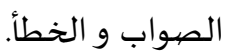

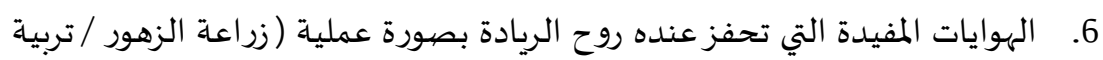

العصافير / صناعة الدمى /صناعة الحلويات).

\section{مفاهيم ومهارات الفكر الريادي لطفل الروضية:}

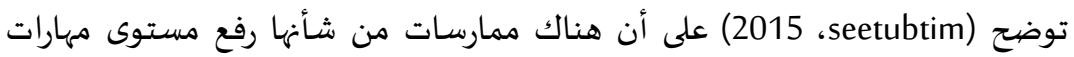

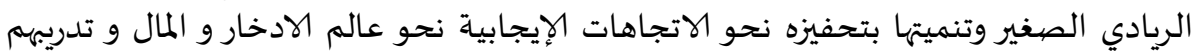

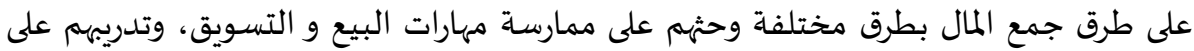

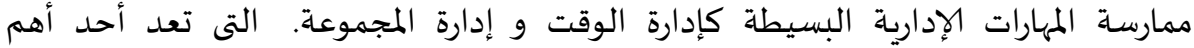
أساسيات عقلية رائد الاعمال . المارية البسط

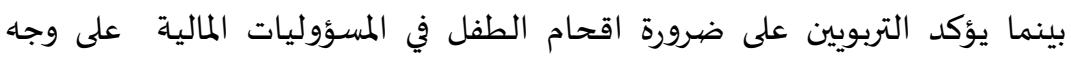

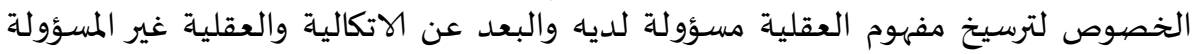

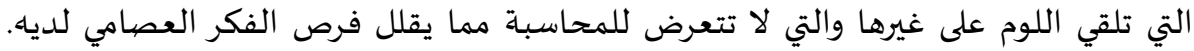

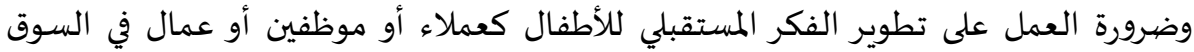

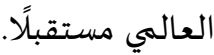

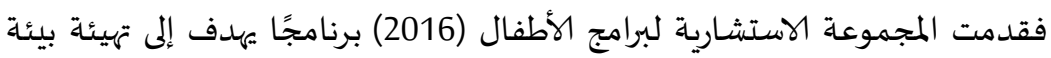

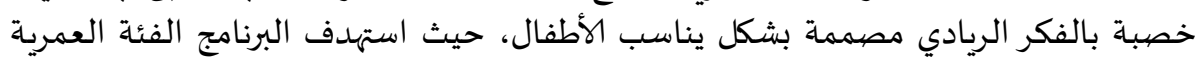

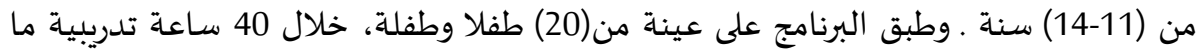

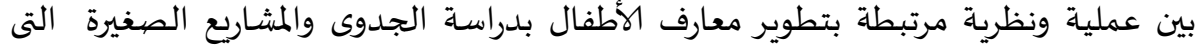

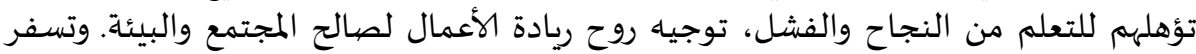

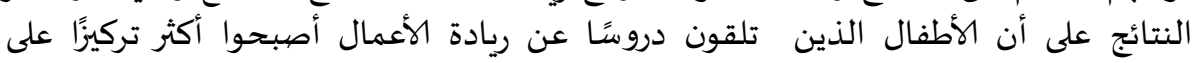

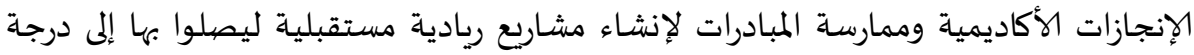
من المهنية والإتقان تؤهلهم لأن يصبحوا رواد أعمال مؤثرين.

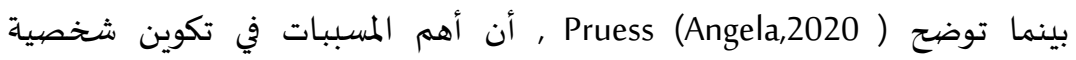

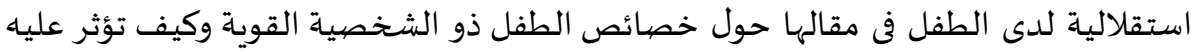

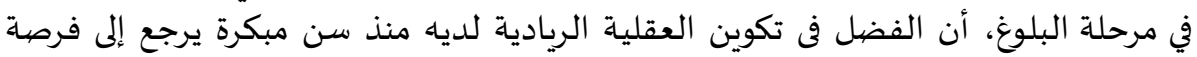

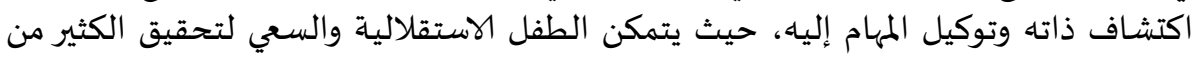

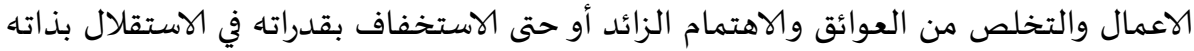

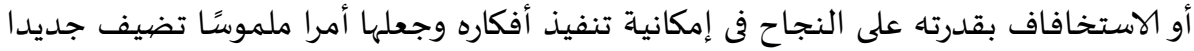




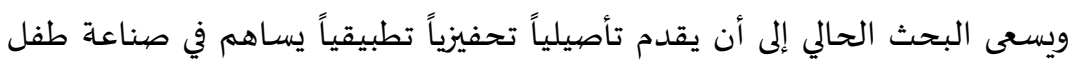

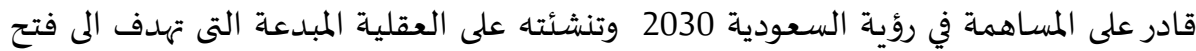

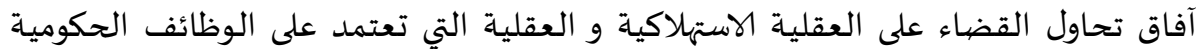

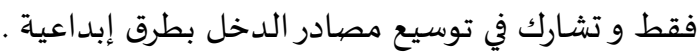
منهجية البحث وأدواته: في ضوء مشكلة البحث وفروضها تم إعداد إجراءاته على النحو التالي: أولًا: مجتمع البحث وعينته:

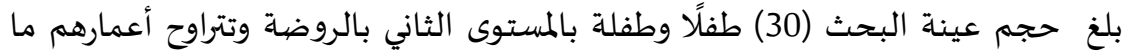

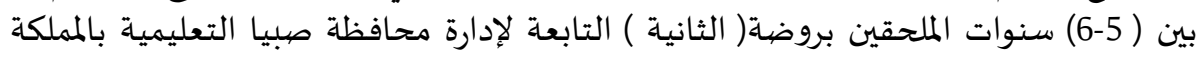
العربية السعودية.

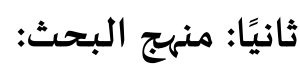

اعتمد البحث الحالي على المنهج شبه التجريبي( التصيميم التجريبي ذو العينة الواحدة)،

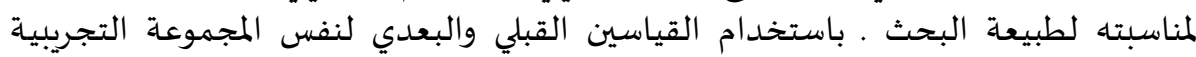
لمعرفة أثر الأنشطة اليدوية ( المتغير المستقل ) في تهيئة التفكير الريادي لطفل الرئل الروضية بأبعادها.

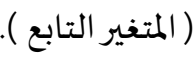

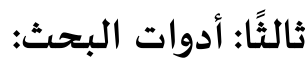
بطاقة ملاحظة تهيئة تفكير طفل الروضية لتفكير بعقلية ريادية: هذا وقد مرت اعداد بطاقة الملاحظة حتى وصلت الى صيورتها الهائية في عدد من الخطوات يمكن اجمالها فيما يلي: الهدف من بطاقة الملاحظة: 1. تهدف هذه البطاقات الى قياس أداء طفل الروضة للتهيئة للتفكير بعقلية ريادي صغير.

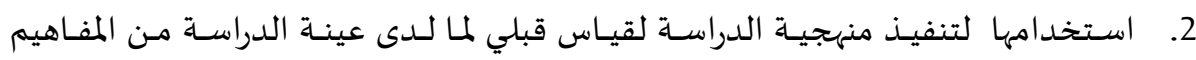

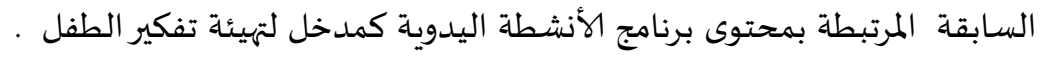
3. استخدامها لقياس بعدى لمدى فاعلية برنامج الأنشطة بعد التطبيق . وصف بطاقة الملاحظة:

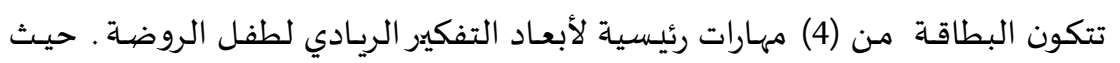

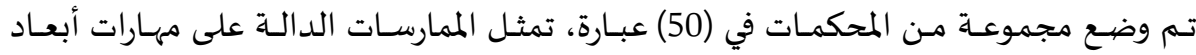

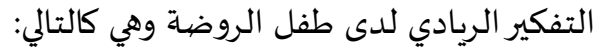
البعد الأول: المبادأة و المبادرة : ويتضمن (11) عبارة تصف لتروفيه الأداء المتوقع للطفل 
البعد الثاني: الحداثة والجدة في الأفكار ويتضمن (13) عبارة تصف الأداء المتوقع للطفل البعد الثالث: الاستقلالية في الإنجاز: ويتضمن (7) عبارة تصف الته الأداء المتوقع للطفل البعد الرابع: المخاطرة المحسوبة: ويتضمن (19) عبارة تصف الأنساء المباء المتوقع للطفل

تحديد أسلوب تسجيل الملاحظة:

\begin{tabular}{|c|c|c|}
\hline التقدير الكهي & مستوى الأداء & م \\
\hline 1 & لا أداء للمهارة & 1 \\
\hline 2 & أدى المهارة بشكل ناقص & 2 \\
\hline 3 & أدى المهارة بشكل تام & 3 \\
\hline
\end{tabular}

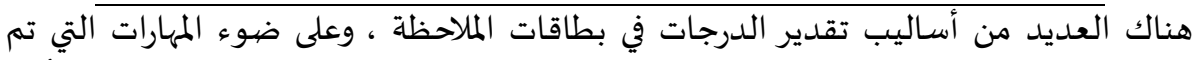

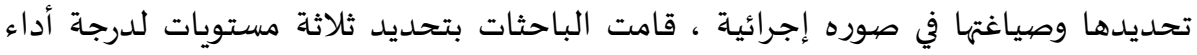

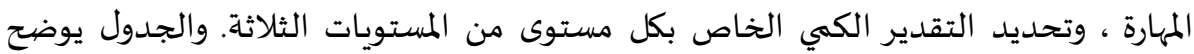

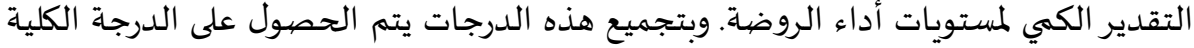

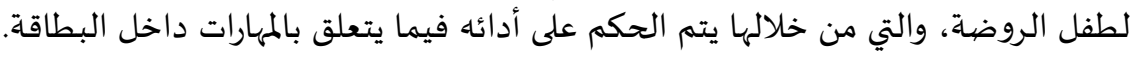

\section{حساب صيدق بطاقة الملاحظة:

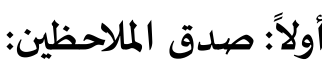

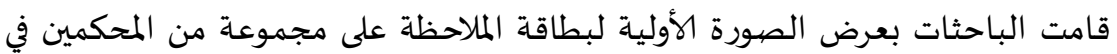

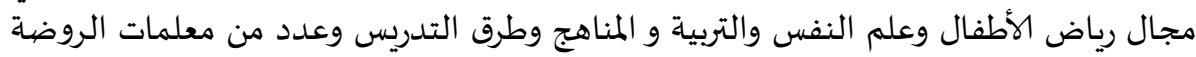

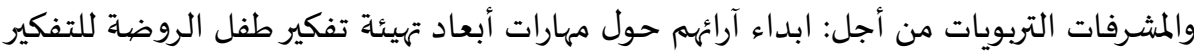

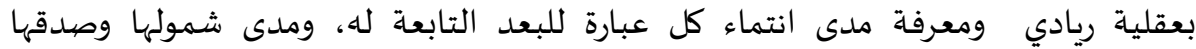

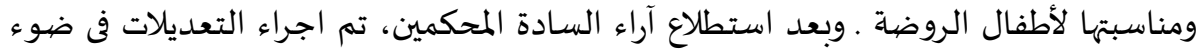

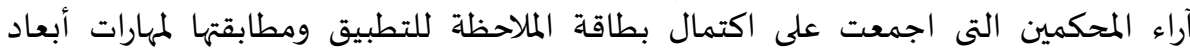

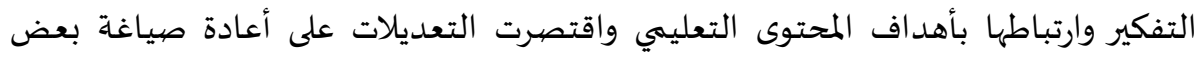

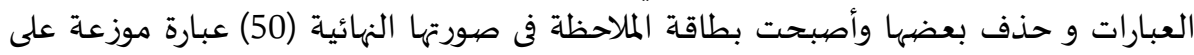

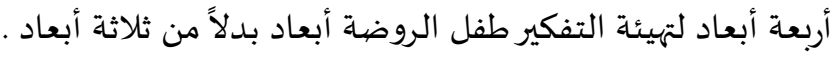

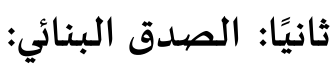

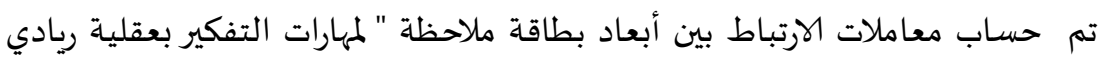

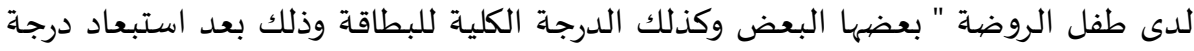

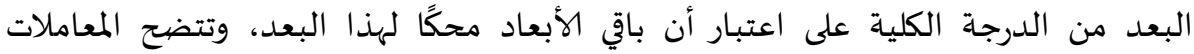
بالجدول التالي: 


\begin{tabular}{|c|c|c|c|c|c|}
\hline \multicolumn{6}{|c|}{ الروضية: } \\
\hline الملدرجة & المحسوبة المخرة & في الانجازلية & الحجداثة الحأفكار في & المبادأة & محاور بطاقة \\
\hline$* * 0.915$ & $* * 0.575$ & $* * 0.628$ & $* * 0.624$ & - & المبادأة \\
\hline$* * 0.728$ & $* * 0.512$ & $* * 0.551$ & - & & الحمداثة والجدة في \\
\hline$* * 0.841$ & $* * 0.862$ & & & & الاستقلالية في الانجاز \\
\hline$* * 0.728$ & - & & & & المخاطرة المحسوبة \\
\hline
\end{tabular}

دالة عند مستوى 0.01، دالة عند مستوى 0.05 قيمة "ر" الجدولية عند مستوى دلالة 0.01 ودرجة حرية .0.449=30

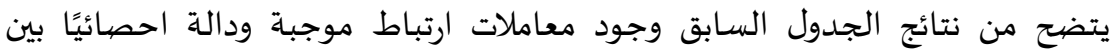

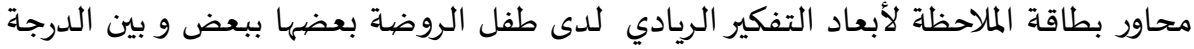

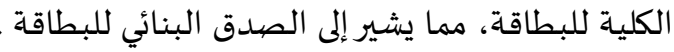

حساب ثبات بطاقة ملاحظة مهارات التفكير الريادي لدى طفل الروضية: ] مبات بطاقة الملاحظة: طريقة إعادة التطبيق:

تم حساب ثبات البطاقة وأبعادها باستخدام طريقة إعادة التطبيق، حيث تم تطبيق

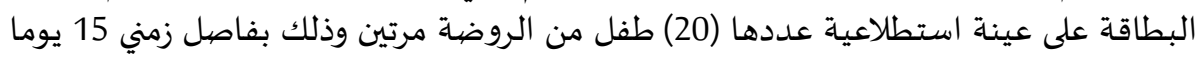

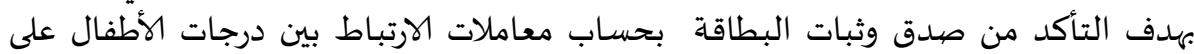

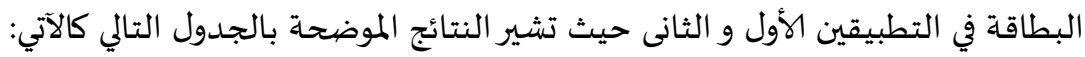
جدول(3) معاملات ثبات بطاقة ملاحظة تهيئة التفكير الريادي لدى طفل الروضة وأبعادها

\begin{tabular}{|c|c|}
\hline معامل الثبات & أبعاد التفكير الريادي \\
\hline 0.718 & المبادأة \\
\hline 0.698 & الحداثة في الأفكار \\
\hline 0.826 & الاستقلالية في الانجاز \\
\hline 0.669 & المخاطرة المحسوبة \\
\hline 0.843 & الدرجة الكلية \\
\hline
\end{tabular}


يتضح من نتائج الجدول السابق تمتع بطاقة ملاحظة " ههيئة التفكير الريادي لدى طفل بلدي الروضاة وأبعادها" بمعاملات ثبات مرتفعة، مما يشير الى الاطمئنان إلى نتائجها .

ثالثًا: برنامج مهارات التفكير الريادي لطفل الروضية:

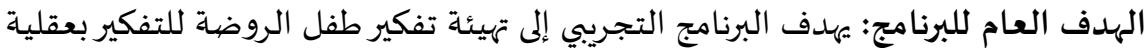

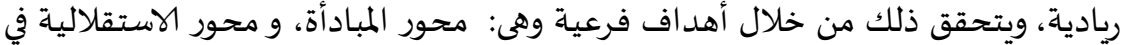

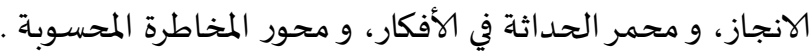

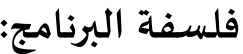

تعتمد فلسفة البرنامج على فلسفة الأنشطة اليدوية التي تتناول العديد من المهارات

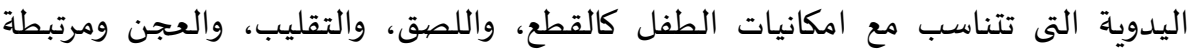

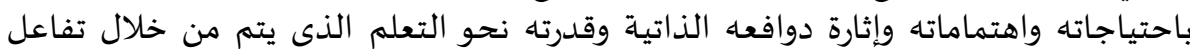
الطفل مع مختلف الخامات والمستهلكات البيئية

\section{تصيميم محتوى البرنامج:}

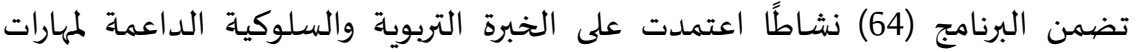

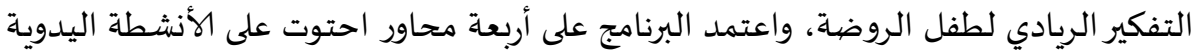

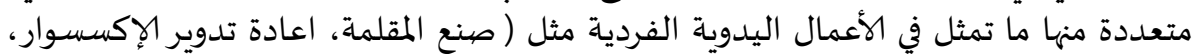

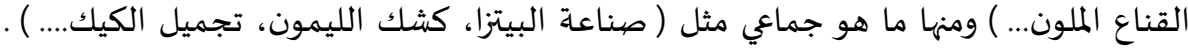

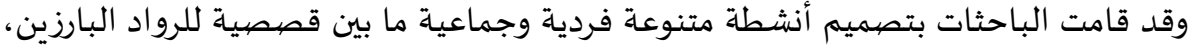

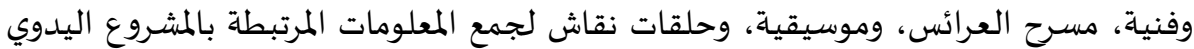

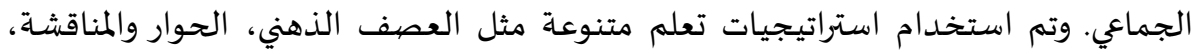

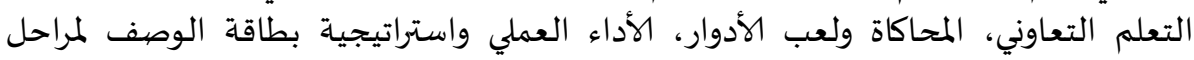

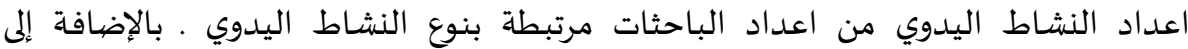

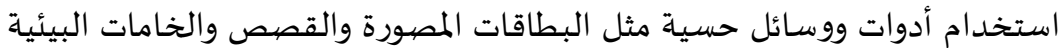

تم تحديد المدى الزمنى للبرنامج وعدد الأنشطة والوقت الذى يستغرقه كل نشاط،

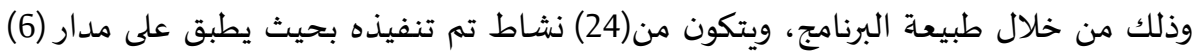

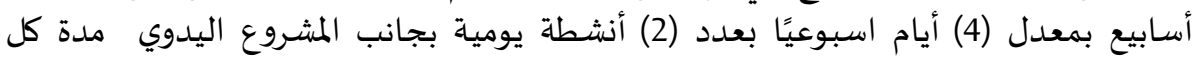
نشاط ما بين (25 - 30) دقيقة .

$$
\text { أساليب تقويم البرنامج: }
$$

] تقويم قبلي: تم تطبيق أدوات البحث ( بطاقة ملاحظة مهارات التفكير بعقلية ريادية ) قبليًا

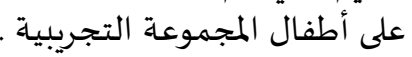

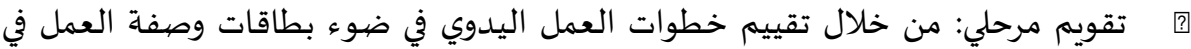

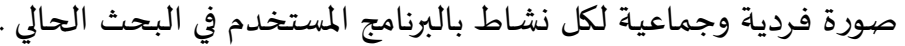


تم اجراء المعالجات الاحصيائية باستخدام برنامج (spss) لتحديد المتوسطات الحسابية

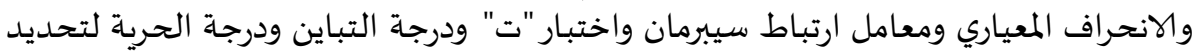
اتجاه الدلالة لاستخراج النتائج وتفسيرها.

$$
\text { نتائج البحث وتفسيرها: }
$$

أولاً عرض نتائج الفرض الأول والذى ينص علي:-

توجد فروق دلالة احصائية عند مستوى دلالة (5.،) بين متوسطي درجات المئية الأطفال في

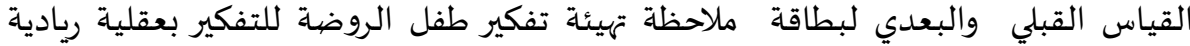

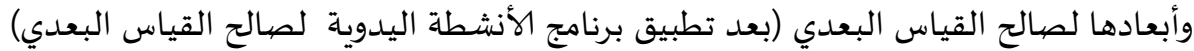
وللتحقق من صحة هذا الفرض وأبعاده تم مقارنة متوسطات درجات أطفال المجموعة المبات

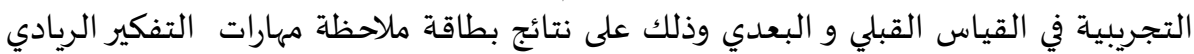

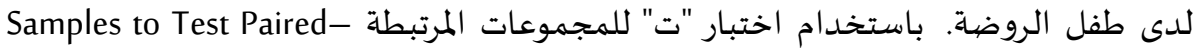

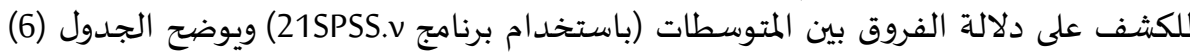

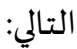

جدول (6) المتوسطات والانحرافات المعيارية وقيم "لدرجات أطفال المجموعة التجريبية في

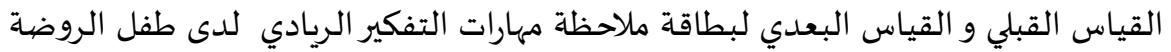

\begin{tabular}{|c|c|c|c|c|c|c|c|}
\hline مستوى & قيمة ت & الحرية & المعياري & المتوسط & العدد & القياس & محاور البطاقة \\
\hline \multirow{2}{*}{0.01} & \multirow{2}{*}{68.97} & \multirow{2}{*}{29} & 1.40 & 13.40 & 30 & القبلي & المبادأة \\
\hline & & & 0.62 & 29.76 & 30 & البعدي & \\
\hline \multirow{2}{*}{0.01} & \multirow{2}{*}{107.72} & \multirow{2}{*}{29} & 0.73 & 14.46 & 30 & القبلي & \multirow{2}{*}{ الحداثة في الأفكار } \\
\hline & & & 1.24 & 34.96 & 30 & البعدي & \\
\hline \multirow[b]{2}{*}{0.01} & \multirow[b]{2}{*}{83.50} & \multirow[b]{2}{*}{29} & 0.71 & 7.66 & 30 & القبلي & \multirow{2}{*}{ الاستقلالية في } \\
\hline & & & 0.76 & 18.80 & 30 & البعدي & \\
\hline \multirow{2}{*}{0.01} & \multirow{2}{*}{121.71} & \multirow{2}{*}{29} & 1.86 & 21.03 & 30 & القبلي & \multirow{2}{*}{ المخاطرة المحسوبة } \\
\hline & & & 1.36 & 51.06 & 30 & البعدي & \\
\hline \multirow{2}{*}{0.01} & \multirow{2}{*}{171.90} & \multirow{2}{*}{29} & 3.60 & 56.68 & 30 & القبلي & \multirow{2}{*}{ الدرجة الكلية } \\
\hline & & & 3.41 & 135.62 & 30 & البعدي & \\
\hline
\end{tabular}


يتضح من الجدول السـابق ما يلي:

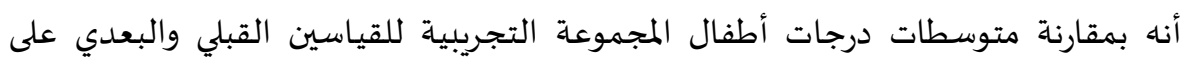

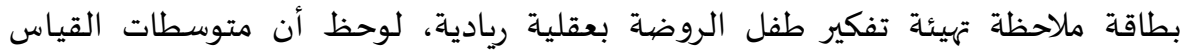

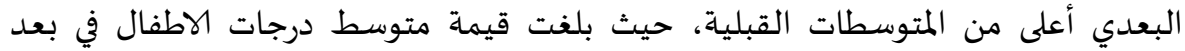

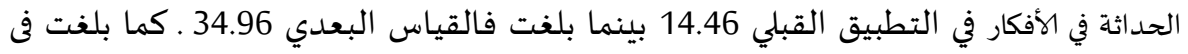

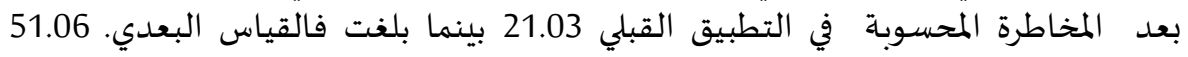

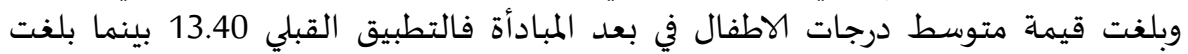

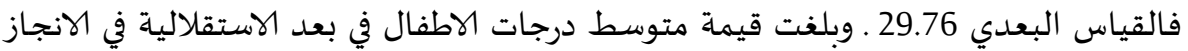

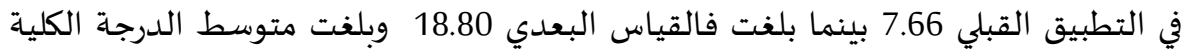
على بطاقة ملاحظة تهيئة تفكير طفل الروضانة للتفكير بعقلية رئليادية

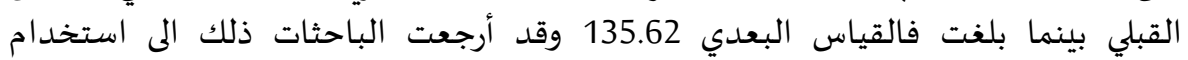
الانشطة اليدوية وفاعليتها علي المجموعة التجريبية.

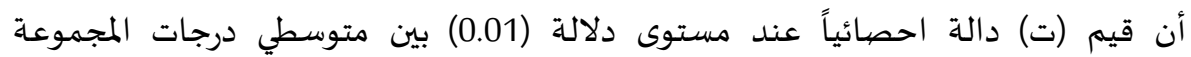

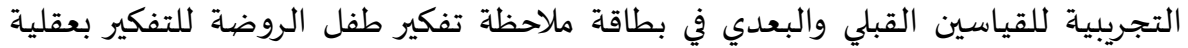
ريادية وأبعادها الأربعة. وهذا يعني قبولي البعدي الفرض الأول وفروعه.

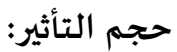

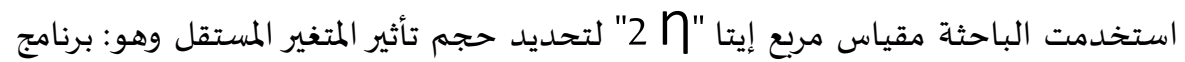

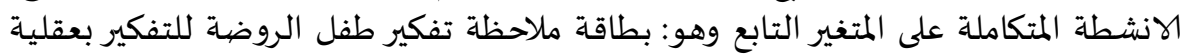

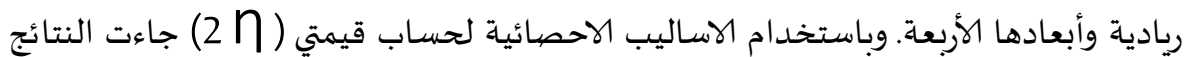
كما هي موضحة في الجدول التالي (7):

\begin{tabular}{|c|c|c|c|c|c|}
\hline الدرجة الدية & المحسوبة & الاستقلالية في & الحداثة و الجأجدار & المبادأة & أبعاد البطاقة \\
\hline 171.90 & 121.72 & 83.50 & 107.73 & 68.98 & قيمة ت \\
\hline 0.99 & 0.98 & 0.97 & 0.97 & 0.96 & "2n" مربع ايتا \\
\hline 19.90 & 12.60 & 11.73 & 11.73 & 9.37 & قيمة d \\
\hline كبير & كبير & كبير & كبير & كبير & حجم التأثير \\
\hline
\end{tabular}

كما كان حجم تأثير برنامج الأنشطة اليدوية كبيرا فالمحاور الفرعية لبطاقة ملاحظة تفكير المارئ

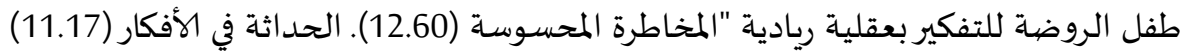

المبادأة (9.37) الاستقلالية في الانجاز (11.73). 


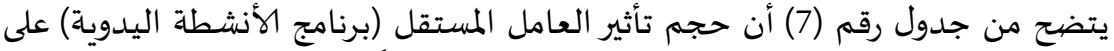

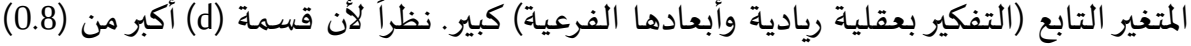

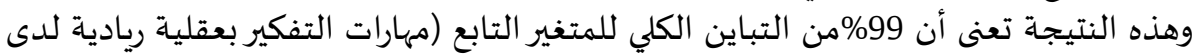

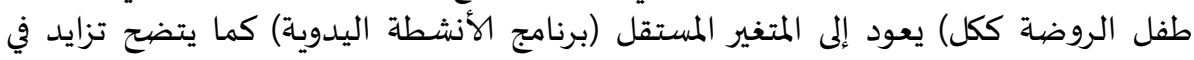

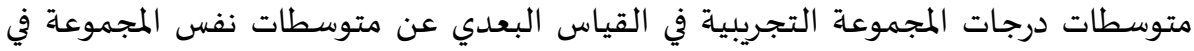

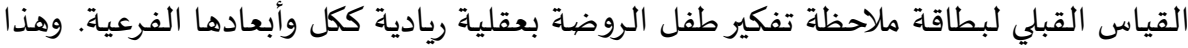

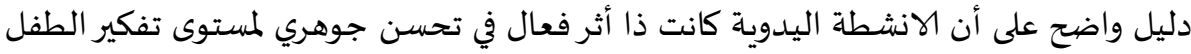

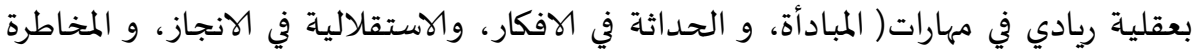

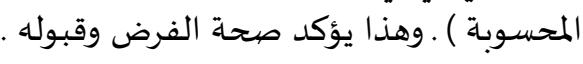

وبالتالي يمكن القول من خلال النتائج التي توصلت إلهها الدراسة الحالية وكذلك النتائج

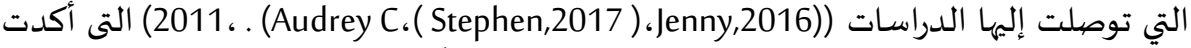

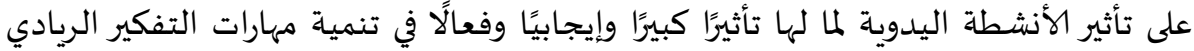

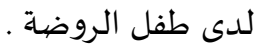

\section{ثانيًا: عرض نتائج الفرض الثانى والذى ينص علي:-}

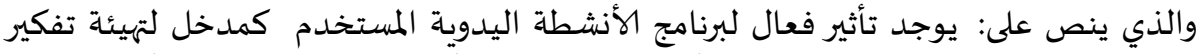

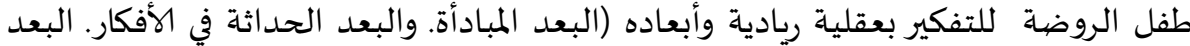
الاستقلالية في الانجاز. البعد المخاطرة المحسوسة) كما تقيسها بطاقة المبادة الملاحظة. ولذلك قامت الباحثة باستخدام معادلة الكسب المعدل لبلاك من خلال حساب درجات القياسين القبلي والبعدي لبطاقة الملاحظة وأبعادها والجدول التالي يوضح المعادلة تلك النتائج.

جدول (8) نسبة الكسب المعدل لبلاك لبطاقة ملاحظة تفكير طفل الروضة

\begin{tabular}{|c|c|c|c|c|c|}
\hline \multicolumn{6}{|c|}{ للتفكير بعقلية ريادى } \\
\hline الدلالة & الكسبة & المتعدسي & المتوسطي & العظهى الهاية & ابعاد البطاقة \\
\hline فعال & 1.33 & 29.76 & 13.40 & 33 & المبادأة \\
\hline فعال & 1.36 & 34.96 & 14.46 & 39 & الحداثة والجدة في الأفكار \\
\hline فعال & 1.37 & 18.80 & 7.66 & 21 & الاستقلالية في الانجاز \\
\hline فعال & 1.36 & 51.06 & 21.03 & 57 & المخاطرة المحسوبة \\
\hline فعال & 1.36 & 134.63 & 56.66 & 150 & الدرجة الكلية \\
\hline
\end{tabular}

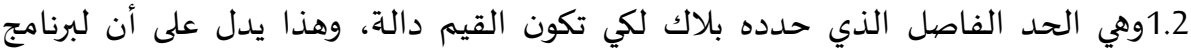

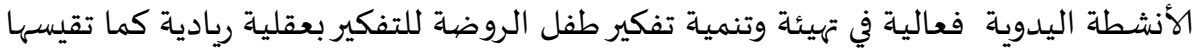


بطاقة الملاحظة. وتعزى هذه النتائج إلى أن الأنشطة اليدوية المختلفة التى تتمتع بمهارات

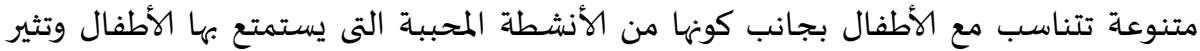

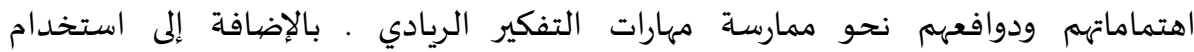

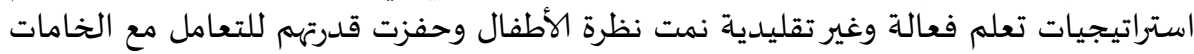

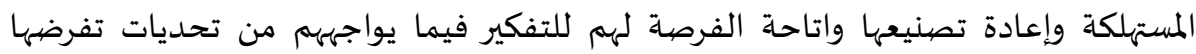

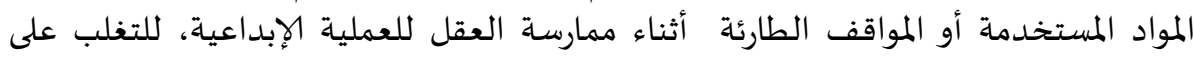

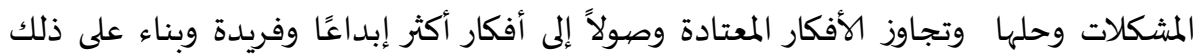

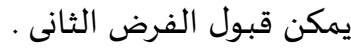

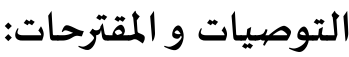

يوصى البحث في ضوء النتائج التي توصل إليها بما يلى:

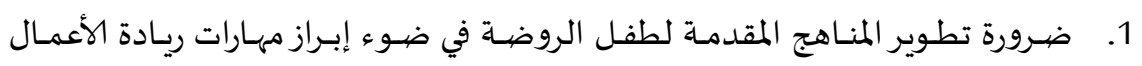

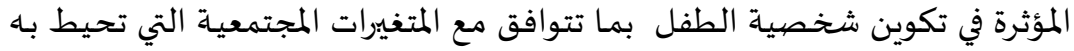

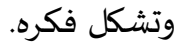

2. إعداد برامج الأنشطة اليدويـة والأدلة الإرشادية للقائمين على تعليم طفل الروضية وتستهدف تعزيز مهارات التفكير بعقلية ريادية.

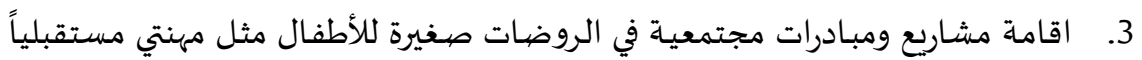

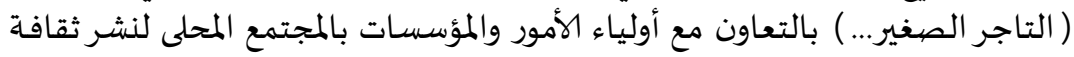
المواطنة المسئولة وريادة الأعمال.

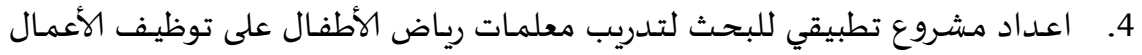

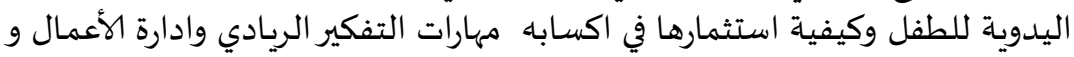

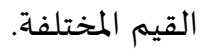

5. ضرورة تبنى برامج الأطفال بالقنوات الفضائية المختلفة وقنوات الأطفال المتخصصية

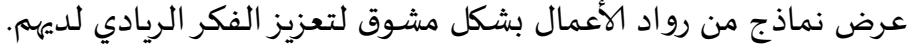

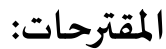

يقترح البحث دراسات أخرى مكملة له في المجال من أهمها:

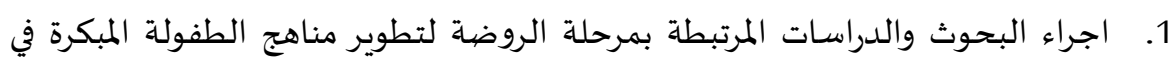
ضوء المتغيرات العالمية لما لها من تأثير بالغ في تشكيل شخصية المرات الطية الطفل الريادية مثل

$$
\text { دراسة: - n }
$$

- فاعلية برنامج تدريبي قائم على استراتيجية المشروع ودورها في تنمية بعض مهارات

$$
\text { الفكر الريادي لطفل الروضية. }
$$

- فاعلية تأثير الحكايات الشعبية كمدخل لإكساب مهارات ريادة الأعمال لدى طفل

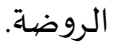


كلية التربية بالقاهرة: العداد: (188)، الجزء (الثالث)، أكتوبر لسنة 2020م

تقويم أنشطة منهج الروضة لمعرفة تأثيرها لتحسين مستوى عقلية الطفل الريادية

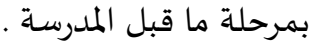

- - أثر مسرح العرائس في تنمية مهارات ريادة الأعمال لدى طفل مرحلة الطفولة المبكرة.

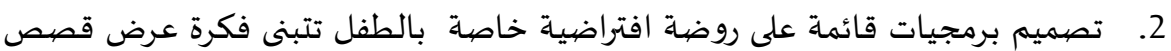

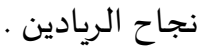




\section{قائمة المراجع}

\section{أولًا: المراجع العربية}

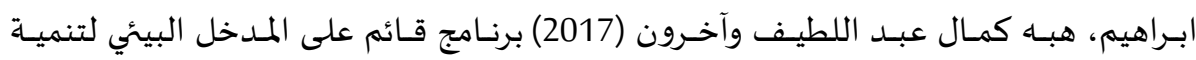

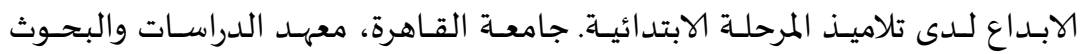

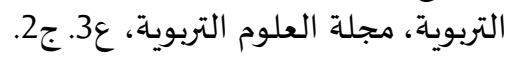

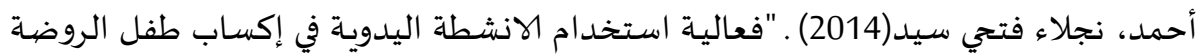

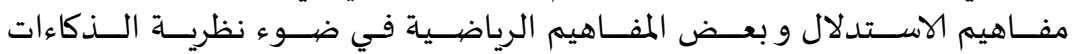

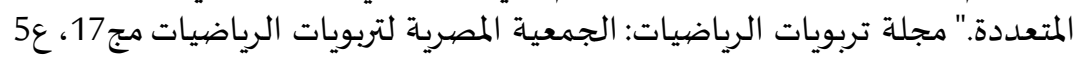

226 - $220: 2014)$

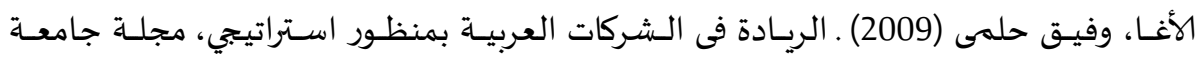

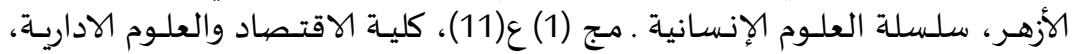
الجامعة الاسلامية بغزة.

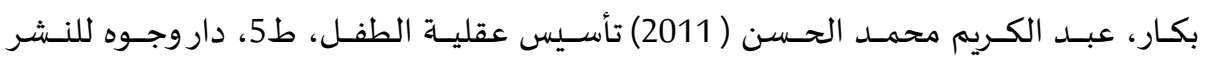

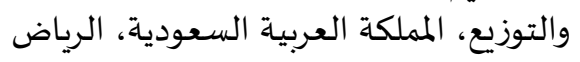

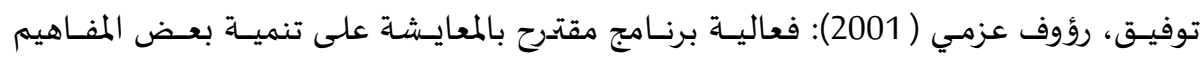

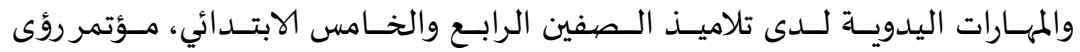

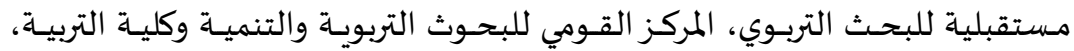

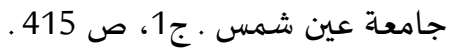

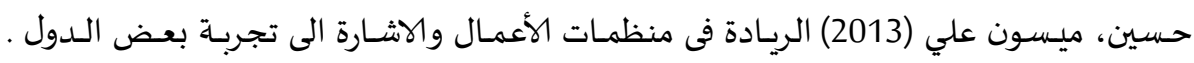
مجلة جامعة بابل، مجلة العلوم الانسانية، مجلد 21 2013، عدد2.

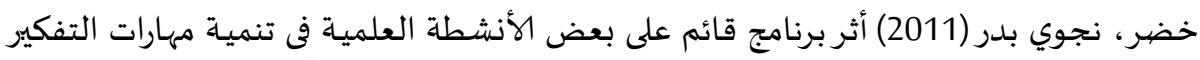

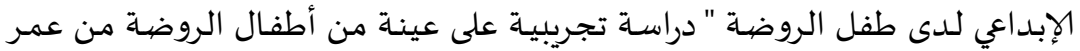

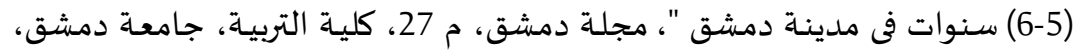
ص ص زايد، منى حلى (2020) فعالية برنامج تدريبي قائم على استراتيجية حل المشكلات لتنمية مهارة التمارية

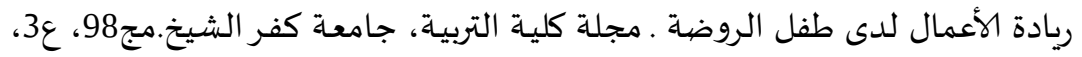

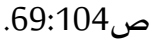

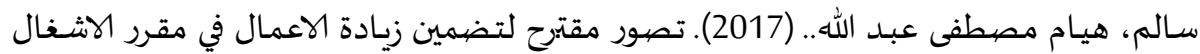

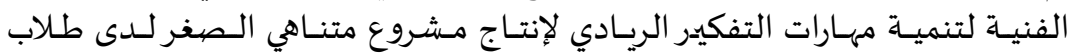

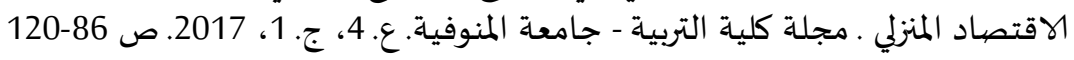




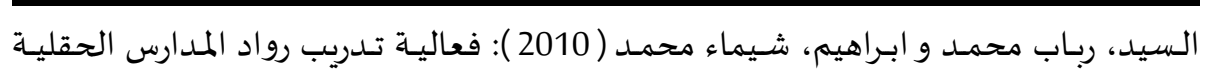

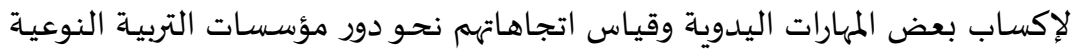

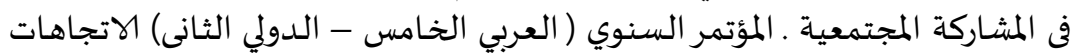

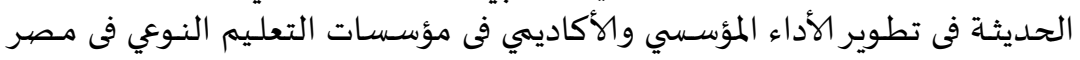

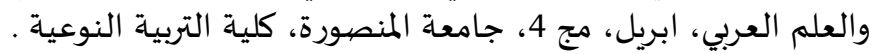

الشميرى، أحمد، المبيرك، ووفاء (2011) . ريادة الأعمال، ط2، الرياض، مكتبة الشقري . شـيب، ناديـة (1990): النششطة اليدويـة في المدرسـة الابتدائيـة، التربيـة، ع 93، قطـر، اللجنــة الوطنية القطرية للتربية والعلوم .

صلاح صالح معمار وآخرون (2019): ريادة العمال للصغار . مركز ديبونو لتعليم التفكير .عمان، الوردن.

الطـاهر، سـحر رؤوف سـعيد(2011 ) مقالـة عـن " الاعمــال اليدويــة ". كليـة الفنـون الجميلـة، جامعة بابل.

عبـد المجيـد، مـروان عمـران 2013) تأثير الفنـون على تنميـة القـدرات العقليـة للأطفال، جامعــة

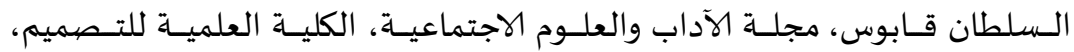

مسقط.

علواني، محمد ( 2018): ريادة الأعمال..ورؤيـ2030، مجلة رواد الأعمال، وكالة سـواحل الجزيرة

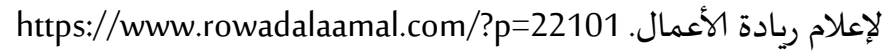

عـويس، رزان (2009): فاعليـة برنـامج تـدريب معلمـات ريـاض الأطفـال على تنميـة بعض مهارات

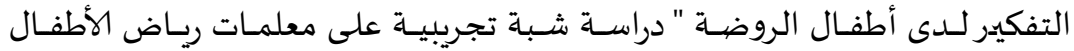

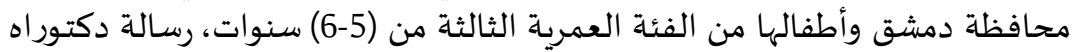

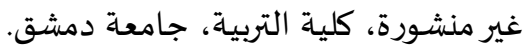

غيبـة، وفـاء أحمــ(2017) مـن الـصفر الى الفخـر " كيـف تـربين أبنًا مميـزًا" . داروجــوه للنـشر

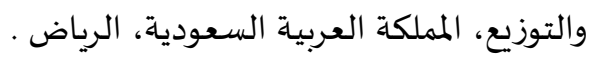

فرمـاوى، محمــد فرمـاوى (1995) المهـارات اليدويـة والعينيـة فى ريـاض الأطفـال، دار الكتـب، القاهرة.

المجموعـة الاستشـارية بـرامج للأطفـال (2016) مـن اجـل تنميـة مهـاراتهم الابداعيـة والرقميـة و ريادة اعمال الاطفال.

محمـود، عمـاد عبـداللطيف (2017): التربيـة الرياديـة ومتطلباتها مـن التعلـيم الجـامعي، مجلـة

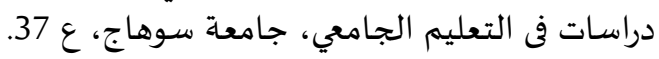




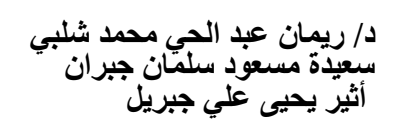

الأنثطة اليدوية كمدل لتهيئة طفل الروضة للتفكير بعقلية ريادي

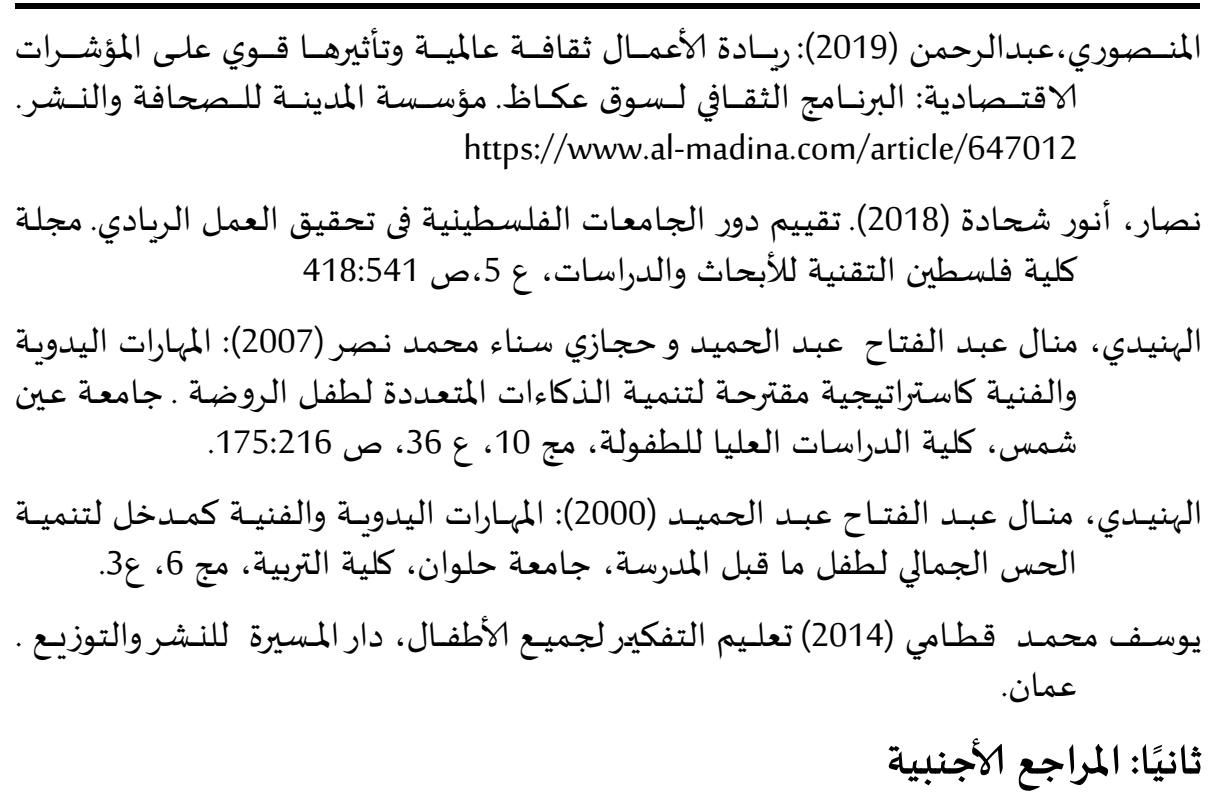

Audrey C. Rule (2011), Creative Product Problem-Solving Game: Exploring Torrance's Creative Strengths by Making an Object from a Set of Given Materials, University of Northern Iowa ,P: 22

Belcastro, S. M. \& Yackel, C. (2008), Making mathematics with needlework. AK Peters Ltd, Wellesley, MA. Retrieved on December 18th, 2016 from:

Dweck, C. (2006)., Mindset: The new psychology of success. New York: Random House.

http://www.crcnetbase.com/doi/pdf/10.1201/b10652-1

Frantz, Dana \& Recchia ,Susan ( 2013), Parent Perspectives on How a child - centered preschool Experience Shapes children's Navigation of kindergarten . Early childhood Research \&practice .v15, N1. Http:ecrp.uiuc.edu/v15n1 recchia/html.

Fancsali, Stephen E.; Yudelson, Michael V.; Berman, Susan R.; Ritter, Steven (2018), Intelligent Instructional Hand Offs, International Educational Data Mining Society, Paper presented at the International Conference on Educational Data Mining (EDM) 11th, Raleigh, NC, Jul 16-20.

Glaveski, Steve (2020) ,Asuccess story in teaching children entrepreneurship.

https://www.collectivecampus.io/blog/lemonade-stand-asuccess -story -in-teaching-children-entrepreneurship. 
Guiti, Nabavi (2017), 5 Strategies to Foster Entrepreneurial Mindset in Children, startup wonder.

https://www.startupwonder.com/5-strategies-to-fosterentrepreneurial mindset-in-children.

Groth, C. (2015)., Emotions in risk-assessment and decision-making processes during craft practice. Journal of . Research Practice, 11(2), article M5

Hedreen, Siri (2019), Why Kids Should Be Taught to Have an Entrepreneurial Mindset, student and Edinburgh Festivals Magazine https://www.business.com/articles/kids-should-betaught-to-think-like-entrepreneurs/

Jenny Evolution (2016), what are the benefits of arts and crafts for kids?,

March 16, 2016 at 12:13 pmhttps:// mommyevolution. Com /what-are-the-benefits-of- arts-crafts- for-kids/

Jodie, Cook (2020 ), How To Raise Entrepreneurial Kids, Jul 13, 2020,03:30am EDT,

https://www.forbes.com/sites/jodiecook/2020/07/13/how-toraise-entrepreneurial-kids

Kathryn Hatter( 2014), "What Are the Benefits of Arts \& Crafts for Children?. www.livestrong.com, Retrieved 20-12-2017. Edited

Kay , Baker (2013), The Significance of the Hand for the Elementary Years The NAMTA Journal, Vol. 38, No. 2 , Spring 2013.

Kola.Olusanya (2005), Free choice environmental education: understanding where children learn outside of school. Environmental Education Research,11(3) 279-300.

Little, Michael H., Cohen-Vogel, Lora (2016), Too Much Too Soon? An Analysis of the Discourses Used by Policy Advocates in the Debate over Kindergarten, Education Policy Analysis Archives, v24 n106 spec is Oct 2016.

Michaelidou, Anna (2015), The Importance of Arts and Crafts in Child Development. First Tutors: Arts \& Crafts, unitedkingdom.

https://www.firsttutors.com/uk/art/blog/2015/12/the-importanceof-arts-and-crafts- in child-development..

Minna Huotilainen, Mimmu Rankanen, Camilla Groth, Pirita Seitamaa-Hakkarainen and Maarit Mäkelä (2018), Why our brains love arts and crafts, Vol.11 Nr.2, Art 1 www.FormAkademisk.org. 
Mohammad Ayyub (2017) Effects of Physical Activity on Motor Skills and Cognitive Development in Early Childhood: A Systematic Review, H.-X. Wang Article ID 2760716,13 p, https://doi.org/10.1155/2017/2760716

Pat Ludick (2013): The Work of the Hand, The NAMTA Journal • Vol. 38, No. 2

Pruess, Angela ( 2020) ,10 Strong Willed Child Characteristics and How They'll Pay off in Adulthood, https://parentswithconfidence.com/strong-willed-childcharacteristics/

Rampton ,John (2018) ,Ways to Teach Your Kids Entrepreneurship Early in Life. Business Tips, Thursday, November 15th. https://www.calendar.com/blog/9-ways-to-teach-your-kidsentrepreneurship-early-in-life/

Reeves ,Stephen (2017), What are the Benefits of Arts and Crafts for Kids.

https://www.knittersagainstbush.com/benefits-arts-crafts-kids

Seitamaa-Hakkarainen, P., Huotilainen, M., Mäkelä, M. Groth, C. \& Hakkarainen, K. (2016) How can neuroscience help to understand design and craft activity? The promise of cognitive . Neuro science in design studies. FORMakademisk, 9(1), Article 3, 1-16.

Soholt, Polli .(2013) ,Practical Life for the Older Children in the Casa.

NAMTA Journal, v38 n2 p57-65.

Thorstinsson, GISLI (2012 ): The Intelligence OF The Hands: Studying The Orgine OFPEDAGOGICAL CRAFT EDUCATION, University of Iceland, ARTICLE in imanager's Journal on Educational Psychology, Vol. 51No. 3 November 2011 - January 2012.

Webster, James (2015 ), Practical Life from the Second Plane to Third Plane: Orientation to History and Social Organization NAMTA Journal, v40 n3 p77-91 